\title{
CRÓNICA E IMAGEN: LA REPRESENTACIÓN VISUAL MONSIVAISIANA DE LO URBANO Y LAS CONTRADICCIONES DE LA MODERNIDAD MEXICANA
}

\author{
Chronic and image: \\ visual representation of Monsivais of the urban \\ and the contradictions of the Mexican modernity
}

Jairol Núñez Moya*

\begin{abstract}
RESUMEN
El trabajo explora el uso de la imagen en la crónica de Carlos Monsiváis, particularmente en Los rituales del caos (1995), donde la protagonista es la ciudad. En su propuesta, la crónica resulta insuficiente y recurre a compilar imágenes que documentan sus temas e ideas, con el fin de fortalecer su crítica de la realidad social. El cronista realiza no sólo un ejercicio de escritura sino la elaboración de un discurso que toma como base el contexto. En el texto las imágenes nos acercan a lo abordado en las crónicas, dan cuenta de la pluralidad cultural y de los cambios que se han gestado en la sociedad mexicana, lo cual posibita una reflexión sobre las contradicciones de la Modernidad.
\end{abstract}

Palabras clave: Carlos Monsiváis, ciudad, crónica, imágenes, modernidad, México D. F.

\begin{abstract}
The paper explores the use of the image in the chronicle of Carlos Monsiváis, particularly in Los rituales del caos (1995), where the city is the protagonist. In its proposal, chronic is insufficient and uses the images compilation that document its themes and ideas, in order to strengthen their criticism of social reality. The chronicler makes not only a writing exercise but also makes a discourse that is based on the context. The images gives us a closer view of what was stated in the chronicles, show us the cultural diversity and the changes that have been developed in the Mexican society; a reflection of the contradictions of modernity.
\end{abstract}

Key Words: Carlos Monsiváis, chronic, city, images, modern, Mexico city.

En México, la fotografía empieza siendo mero recuento, un testimonio sin otra pretensión que la de aclarar imágenes fundamentales: cómo son los pobres, cómo podemos ver nuestra dignidad y nuestra altivez, cómo son nuestros paisajes naturales y urbanos...

Carlos Monsiváis.

Maravillas que son, sombras que fueron. La fotografía en México.

\footnotetext{
* Universidad de Costa Rica. M. L. Profesor asociado. Costa Rica. Una versión de este trabajo fue presentado en el II Congreso Internacional de Literatura Comparada: Teoría Literaria y Diálogos Interdisciplinarios, Universidad de Costa Rica, abril 2016.

Correo electrónico: jairol.nunez@ucr.ac.cr

Recepción: 21-9-2016 Aceptación: 13-09-2017
} 


\section{Introducción}

En América Latina, la producción de diversas representaciones constituye un recurso útil para comprender la lógica cultural que articula las sociedades. Narrativa y plástica exponen elementos que, en el marco de una identidad múltiple, abogan por un reconocimiento del entorno y, por supuesto, enriquecen el acervo cultural.

A fines de siglo XX, aprehender el contexto y plantear reflexiones críticas de lo que sucede en el entorno, se vuelve insuficiente en la escritura lineal de la crónica. Por ello, la representación visual viene a ser un recurso para fortalecer y complementar la documentación que se hace de la cultura.

En esa disyuntiva, el trabajo de un autor como Carlos Monsiváis resulta importante. Ícono de fin y principio de siglo, en su quehacer se reafirma como testigo histórico y como actor social, de-velando en su proceder retórico-literario elementos del acontecer cotidiano. En su caso, es la ciudad de México la que se consigna en lo escrito; es en ella donde se detiene a pensar y repensar las distintas formas de lo humano, lo cultural.

En su visión de "lo propio" y de las distintas formas que encarnan lo propio, Monsiváis recurre a compilar diferentes imágenes que refuerzan sus temas e ideas, con el fin de fortalecer su crítica de la realidad social. Esto sucede a modo de documentación de lo que escribe en varios textos ${ }^{\dagger}$ pero de forma particular en Los rituales del caos (1995).

En este texto, el autor realiza una propuesta en la cual diferentes crónicas publicadas entre finales de la década de 1970 e inicio de 1990, caracterizan el México de fin de siglo. Pero en el libro incorpora además una sección de imágenes. De esta forma, mediante la caracterización, a través del verbo irónico y crítico, y de lo visual, el autor realiza no solo un ejercicio de escritura sino la elaboración de un discurso que toma como base el contexto que lo constriñe.

Para el cronista recurrir a las imágenes resulta determinante puesto que la realidad va más allá de lo que puede transmitir a través de la palabra. Al respecto señala Rubén Flórez:

Las imágenes 'incorporan ideas inexpresadas' o dicen ideologías expresadas con la elocuencia visual de un gesto, de un rostro o de una frase emblema. Imágenes que son un modelo para conductas urbanas y modernas. La imagen del cine o la fotografía resulta "un pacto entre industria cultural y público (2010, s. p.).

\footnotetext{
† Ejemplos de imágenes que acompañan sus crónicas las tenemos: Días de guardar (2010), Amor perdido (2007), Escenas de pudor y liviandad (1988), Apocalipstick (2010), entre otros. Además, ese afán por la fotografía, las ilustraciones y las imágenes se confirman en su texto Imágenes de la tradición viva (2006) y Maravillas que son, sombras que fueron. La fotografía en México (2012).
} 
Las imágenes nos acercan a lo abordado en las crónicas y nos permiten simbólicamente abstraer ese contexto en el que la multitud, la identidad y el espectáculo, parecen ser las categorías más próximas para agrupar las múltiples temáticas. Cada una de las representaciones por sí misma y en conjunto, dan cuenta de la pluralidad cultural y de los cambios que se han gestado en la sociedad mexicana, sobreponiendo concepciones antagónicas que nos llevan a reflexionar, igual que con el texto, sobre las contradicciones de la Modernidad mexicana.

\section{La crónica como representación y la representación visual}

Diferentes autores se han referido a la crónica desde el cuestionamiento sobre el género (Carrión, 2012; Chillón, 1999; Egan, 2004; Jaramillo, 2012; Rotker, 2005); su ubicación entre el periodismo y la literatura (Chillón, 1999); y su genealogía en relación con los relatos de viajes, la literatura testimonial y la historiografía pre-científica (Chillón, 1999).

En lo que respecta a la producción de la crónica, en América Latina tenemos tres momentos asociados a su expresión: los relatos de los conquistadores, las crónicas modernas del siglo XVIII y XIX, y una nueva etapa hacia fines de siglo XX (Carrión, 2012; Darrigrandi, 2013; Jaramillo, 2012; Montes 2014). En todos ellos, el entorno histórico y el sujeto-objeto representado tienen gran relevancia, siendo determinante el carácter contextual.

De ahí que llama la atención, más allá de la doble especificidad que la crónica ha tenido: la periodística y la literaria (Darrigrandi, 2013), el cultivo por parte de intelectuales, quienes haciendo uso de la prosa narrativa han generado un cambio sustancial en el género. El cambio tiene que ver con la mezcla de realidad y ficción, o dicho de otro modo, con la representación de la realidad que realiza quien escribe. Ello por medio de estrategias que acercan lo escrito al lector, algunas veces desde lo narrativo otras desde lo temático.

Lo cierto es que, en la producción de la crónica media un compromiso por parte del escritor, quien evidencia los hechos que acontecen en la sociedad en la cual se desenvuelve, y busca el desarrollo de técnicas que potencien la recepción de su mensaje. En la representación que se hace en la crónica y en la crónica como representación, el asirse a un tema, dominarlo y expresarlo, resulta ingente, pues quien escribe debe demostrar que conoce lo que refiere, y que puede comprender hondamente las situaciones en su lógica y su humanidad. 
Así, la crónica es caracterizable por la función que desempeña en la construcción de lo que documenta; el uso de estrategias narrativas varias que pondera a manera de prueba la argumentación de los hechos; su descripción e incluso su cuestionamiento. Por tanto, ofrece un retrato global y detallado de personajes, situaciones y ambientes (Jaramillo, 2012), lo cual explica que el objeto-sujeto de representación ha cambiado ante los nuevos patrones económicos, comunicacionales y globales (Carrión, 2012); planteándonos tránsitos en relación con la narración y las técnicas (Chillón, 1999). O como sucede en el caso en estudio, con Monsiváis, yendo más allá en el interés por transmitir el acontecer a través de imágenes.

Hoy, señala Montes que:

La narrativa de la crónica contemporánea sobre los sectores sociales subalternos y marginados (las denominadas minorías o, también, las mayorías excluidas), y el tema del género literario, por su carácter de mediador social que organiza y da sentido a la experiencia sobre lo dado, aparece indisolublemente unido a la mirada que se tiene sobre la cultura (Montes, 2014, p. 20).

Eso es lo que sucede desde fines de siglo XX y a lo que acudimos con Monsiváis, a una preocupación por retratar a la sociedad mexicana.

Con estas transformaciones no se desestima el trabajo del lenguaje, que resulta clave para la expresión, ya que la crónica experimenta una especie de economía con la cual su difusión y aprehensión resulta llamativa. De construcción natural, la crónica se constituye en tropo, el cual se estructura retóricamente dando lugar a un medio de expresión artístico. La crónica viene a ser un pintar con palabras, cuya efectividad estética y contundencia simbólica, genera una voz que inquiere al lector sobre la realidad que se vive. De ahí que la imagen la acompaña y complementa.

Podemos decir que la crónica se erige como un modelo de representación a través del cual aflora el medio en el que se origina el texto, dando lugar a una ilustración crítica del acontecer. La crónica es el medio por el que quien escribe le da significado a la realidad.

En Monsiváis, esta labor resulta sumamente enriquecedora, ya que él, en medio de una serie de transformaciones como las de fin de siglo XX, retrata lo que sucede en la ciudad de México, mostrándonos en la linealidad del texto lo inaprehensible de la realidad, para lo cual hace uso también, de la representación visual. 
Las imágenes nos permiten leer una realidad histórica, nos dicen algo con respecto a lo que se trata de comunicar, tienen sus propias preocupaciones (Barthes, 2005). Por ello, es que accedemos a las imágenes mediante tres niveles de significado: descriptivo, analítico e interpretativo (en la dirección que apunta Berger, 2005, siguiendo a Panofsky, 1983), con el fin de interpretar la imagen y reflexionar acerca de aquello que se representa.

Y es que así como, al igual que en la crónica, en la imagen también hay una demanda. "Se trata de un sentido secundario cuyo significante consiste en un determinado "tratamiento" de la imagen bajo la acción del creador y cuyo significado, estético o ideológico, remite a determinada "cultura" de la sociedad que recibe el mensaje" (Barthes, 1986, p. 13). La relación contextual y la marca que impone el entorno en tiempo y espacio son determinantes para poder ahondar en los posibles significados y en el mensaje. Recuérdese que para Barthes (1986) la imagen es una representación que de forma análoga tiene su asidero en un contexto cultural donde la búsqueda de significados nos lleva a lo ideológico. En el análisis, se lleva a cabo un proceso que va, a través de lo simbólico, desde el mensaje perceptivo al mensaje cultural. Así, la visión de Barthes (1986) de mensaje lingüístico, imagen denotada e imagen connotada coincide con la significación primaria, la significación secundaria y la significación intrínseca de Panofsky (1983), que acompañan la lectura y la visión del contexto, tal cual Monsiváis nos lo posibilita en el texto en estudio.

Estos procedimientos connotativos en la lectura son de interés en la fotografía. No se trata como dice Barthes (1986) de una ilustración de la palabra, por lo que hay que acercarse a la imagen de manera crítica a través de la observación, con lo que podremos identificar una ampliación de lo connotativo, una resignificación o la contradicción.

Con esta perspectiva, la imagen se constituye en una materialización del imaginario social de época y en un medio de acceso a la realidad (Taylor, 2005). Por ello, vemos la necesidad de Monsiváis de recurrir a la imagen, como otro mecanismo retórico que le permite expresar los cambios acaecidos en la Modernidad mexicana. El autor consolida el rápido desarrollo que se da a nivel técnico para la aceptación y el soporte de la imagen, y la incidencia de esta en la manera que se aprehenden, desde la perspectiva de un observador, las realidades (Crary, 2008). 


\section{Las imágenes de Los rituales del caos}

Los rituales del caos lo constituyen 28 crónicas que vieron la luz en las últimas décadas del siglo XX. Originalmente, los textos no fueron escritos para el libro sino más bien como artículos publicados en diarios, por lo que abarcan diferentes temáticas del acontecer mexicano, cuya dinámica social está marcada por la vida en la urbe. En ese sentido, al ser articuladas bajo una visión particular en el texto en estudio, las crónicas cumplen con el propósito que advierte el título: mostrarnos los diferentes rituales del caos que se viven en la ciudad de México.

La escritura viene a ilustrar, ordenar y caracterizar lo que en la realidad es inaprehensible: la aglomeración y la saturación urbana. El cronista documenta lo que él como observador percibe en ese desorden que es la ciudad. Recordemos que para Balandier (1990) el orden es una construcción simbólica, lo cual da muestra del caos reinante y del mito que lo fija como principio de la sociedad. El caos, por tanto, presupone un trabajo oculto y constante, con el fin de develar ese principio y eso es lo que procura el cronista: "el orden y el desorden son como el anverso y el reverso de una moneda: inseparables” (Balandier, 1990, p. 112). O como nos dice el mismo Monsiváis: "esto era en el Principio, cuando el desorden y el vacío se combinaban para sugerir la unidad” (p. 134, cursiva en el original). Unidad que no es tal, de ahí que en el ejercicio intelectual que propicia el texto, se replica la misma forma en que opera la sociedad, en la cual elaboramos mecanismos cognitivos (el orden) que permiten la comprensión del mundo (el caos). Por eso es que el autor se ve en necesidad del uso de un recurso técnico para dar orden al caos: incluir el apartado con imágenes que hemos referido.

"Parábola de las imágenes en vuelo" es una sección del libro precedida por una introducción sobre el cambio demográfico que, junto a ilustraciones y fotografías, muestran ideas, hechos e imaginarios del amplio espectro social de la ciudad de México. Apunta el cronista: "desde las estadísticas, la gente acecha. Allí, en esa plaza fuerte de la demografía, la gente se sabe a salvo y en expansión contínua" (s. p., cursiva en el original). ${ }^{\S}$

En esta "parábola", el principal argumento que se expone es la comprensión del crecimiento poblacional, que se fija como inicio de las crónicas posteriores. Si hay un elemento que sirva de base para lo que se expone, es la multiplicación de la gente: “todo

\footnotetext{
¥ La edición de Los rituales del caos que se utiliza es de la Editorial ERA, 1998. A partir de aquí, solo se indicará el número de página en las citas del texto.

$\S$ El apartado titulado "Parábola de la imágenes en vuelo" no tiene paginación en el texto.
} 
lo que respira, si logra hacerlo, alabe a la demografía" (s. p., cursiva en el original). Así, la multiplicación "reta al infinito y despoja de sentido a las profecías" (s. p., cursiva en el original). Este exceso se traduce en la representación visual, registro de lo que la demografía y el consumo nos heredan; una manera de ver lo que sucede en la urbe.

En este apartado se incluyen dieciséis imágenes, las cuales son, según el orden en el que aparecen: Concierto de la raza, fotografía de David Hernández; El flechador del cielo, pintura de Jesús Helguera; Apolo urbano, fotografía de Armando Cristeto; una fotografía de Jesús Fidencio Síntora Constantino e imagen del El niño Fidencio como santo; una fotografía de Rodolfo Guzmán, El Santo; Gloria Trevi y los condones, fotografía de Maritza López; Viernes Santo en Iztapalapa, fotografía de Marco Antonio Cruz; Julio César Chávez, fotografía de Guillermo Castrejón; Peregrinos en la Basílica, fotografía de Jorge Claro León; Celebración futbolera en el Ángel, fotografía de Jorge Claro León; Balneario, fotografía de Francisco Mata Rosas; El Metro, fotografía de Guillermo Castrejón; Luis Miguel, fotografía de Rogelio Cuéllar; María Félix en el Zócalo, fotografía de Alejandro Brito; y Redada, fotografía de Marco Antonio Cruz.

Todos los fotógrafos son artistas conocidos en el medio cultural mexicano; y, en el caso de Jesús Helguera, este se convirtió en una leyenda de la ilustración mexicana de la primera mitad se siglo."

De las imágenes, resulta importante destacar algunos elementos que se trastocan en relación con lo que ofrecen las crónicas y que nos llevan a explorar relaciones intra e intertextuales.

El Concierto de la raza nos presenta una reunión multitudinaria de jóvenes en un concierto (ver Imagen 1).

\footnotetext{
** La obra de Jesús Enrique Emilio de la Helguera Espinoza (1910-1971) es catalogada como sentimentalista y comercial, ya que se publicó casi exclusivamente en calendarios contratados por la Cigarrera La Moderna S. A. de C.V. Justamente, la visión folklórica de los temas y la masividad de las reproducciones lo antepusieron al canon.
} 
Imagen 1. Concierto de la raza, fotografía de David Hernández

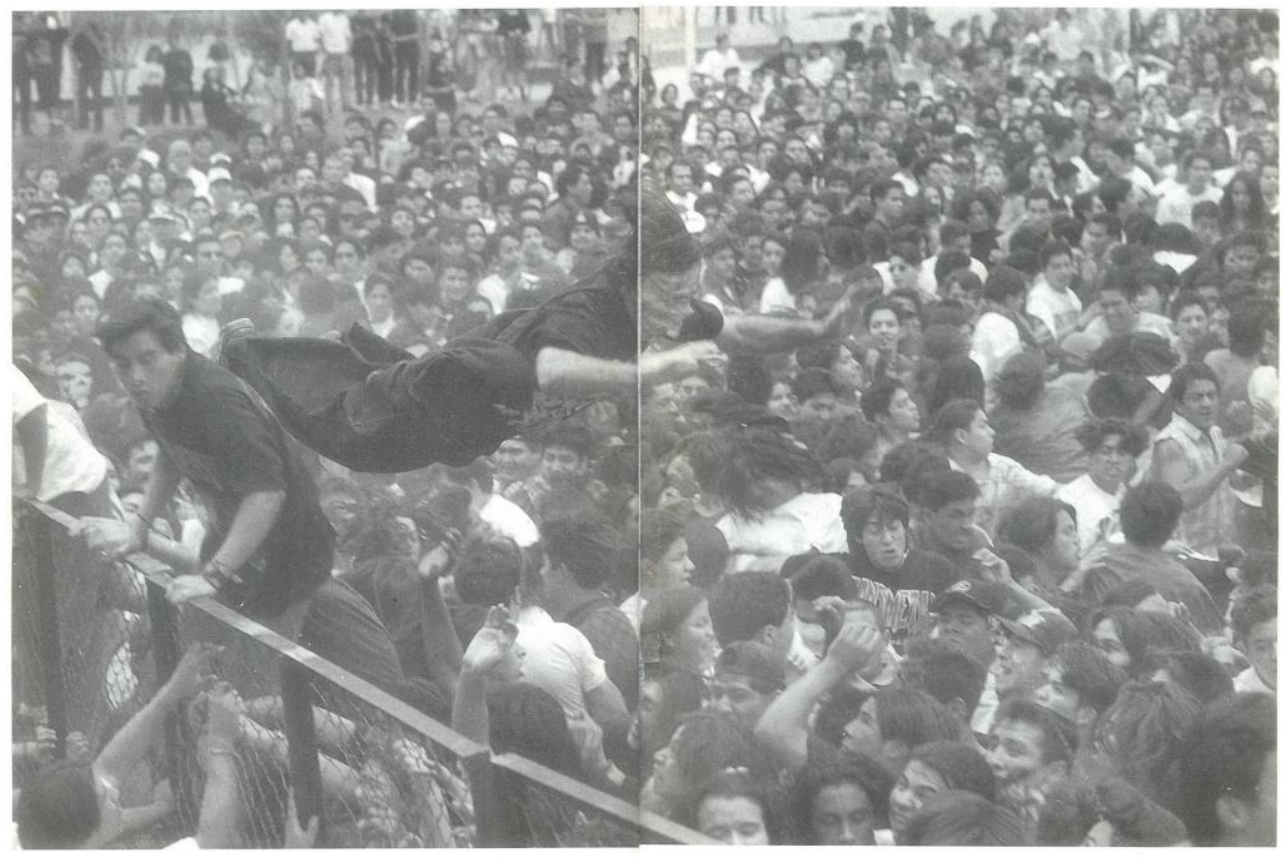

Concierto de la razå @ David Hernández

Fuente: Los rituales del caos de Carlos Monsiváis (1998), imagen para efectos ilustrativos.

La imagen nos recuerda la referencia constante de Monsiváis a la gran cantidad de población que se ha afincado en el entonces Distrito Federal, producto de la migración interna en busca de mejores condiciones de vida. Asimismo, se destaca un joven brincándose una baranda y otro en el aire, lo cual es muestra del mosh o baile que se desarrolla por parte de los jóvenes, principalmente cuando la música es punk o de algún estilo subcultural (Hebdige, 2004; Britto, 1991). Se pone de manifiesto que para Monsiváis, muchos de los elementos subculturales y contraculturales han sido cooptados por el consumo, a pesar de que "la música, la escena que recrea y enamora, conspira a cielo abierto y se ve representada en la historia del rock, las grabaciones de grupos que aún no acceden al disco” (p. 123). Contraposición clara del avance tecnológico y las posibilidades económicas.

El flechador del cielo, representa la perspectiva iconográfica nacionalista basada en el costumbrismo, la cual construye imaginarios sociales con respecto a lo indígena (ver Imagen 2). 


\section{Imagen 2. El flechador del cielo, dibujo de Jesús Helguera}

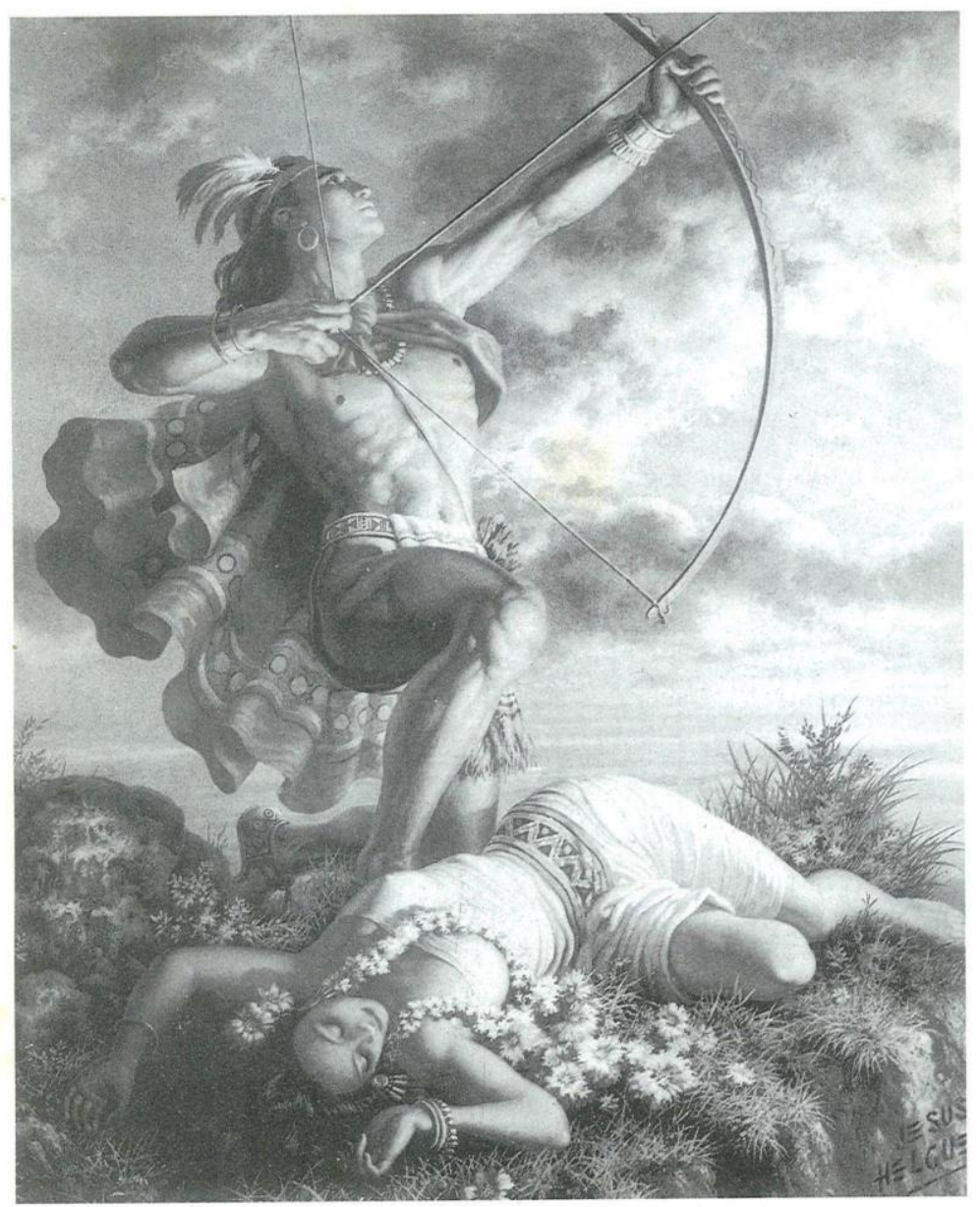

El flechador del cielo $\bullet$ Jesús Helguera

Fuente: Los rituales del caos de Carlos Monsiváis (1998), imagen para efectos ilustrativos.

"Helguera inventa los escenarios o los transfigura a placer, poblándolos con una alegría dulcemente artificial" (p. 67), donde queda expresada una relación con el Otro cultural que, al mismo tiempo, lo toma en cuenta y lo modifica bajo cánones que no corresponden con su realidad sociocultural, una mímesis paródica de la identidad. En términos de Monsiváis (1998) es un modo típico de inventar la tradición, proponiendo a su vez modelos estéticos de lo bello.

En esa dirección, resulta importante, tomar en cuenta, como sucede con la emulación de la tipología humana en tanto modelo de la prospectiva costumbrista mexicana (Segre 2007), que existe en la pintura de Helguera una visión didáctica en la cual se le enseña a ese Otro a ser incorporado dentro del discurso de la nación, pero bajo ciertos cánones o perspectivas que no son del todo incluyentes. Diría Segre (2007) que se da la recreación de momentos que reconocen y comulgan de alguna manera con 
la visión de los lectores, en este caso los amplios grupos populares que toman los calendarios de Helguera como cuadros para decorar sus casas.

La visión del costumbrismo en Helguera permite ver la forma en la cual la perspectiva decimonónica se cuela a través de un proyecto de nación donde el sistema cultural resulta determinante. Este aspecto es clave en la configuración de la identidad nacional mexicana, ya que al igual que sucede en los diferentes procesos de transculturación (Spitta, 1995) existe una tensión entre los grupos que conforman la sociedad, cada uno con prácticas y dimensiones particulares.

El trabajo de Helguera se asienta en lo popular justamente porque evoca la tradición desde un ideal de perfección al que se aspira:

Helguera cree que la Raza de Bronce sólo se salvará, en la teología del impulso nacional, si el aspecto físico la distancia de su destino cruel. Por eso pinta a lo prehispánico como festín de la hermosura de cuerpos inmaculados, "perfiles aristocráticos", torsos labrados, senos opulentos (p. 70).

Esta es la misma perspectiva que se cuela en el Apolo urbano, una imagen de un joven con rasgos fenotípicos que se asemejan a los mexicanos, pero con un cuerpo que recuerda al David de Miguel Ángel (ver Imagen 3). Estos elementos conjugados en una misma imagen nos plantean la transculturalidad (Spitta, 1995) tanto del entorno como del habitante de la ciudad. Recuérdese, además, que la visión de Apolo, simboliza la claridad y la armonía, una especie de orden que es el que se está demandando como parte del acontecer de la urbe. Ese orden sería uno nuevo, en el que se fija la heterogeneidad conflictiva que se encauza a través de lo representado: lo indígena y el clasicismo occidental. Aquí, la transculturación se asume como parte del proceso de modernización, pero también del conflicto dado por su aplicación en contextos no europeos. En ese sentido es que no hay dos caminos, hay un préstamo, un desplazamiento y la re-creación de la realidad (de acuerdo con lo que refiere Segre [2007] de Renato Ortiz). 


\section{Imagen 3. Apolo urbano, fotografía de Armando Cristeto}

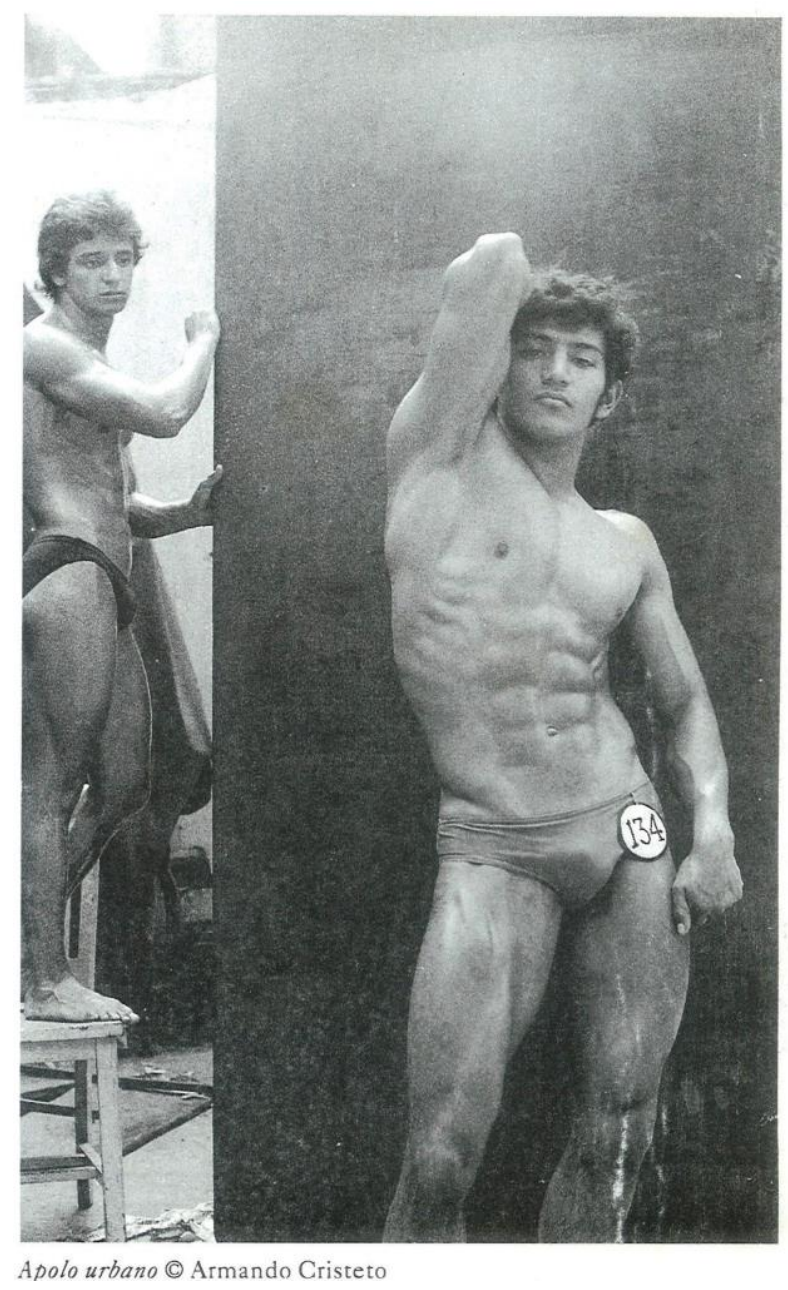

Fuente: Los rituales del caos de Carlos Monsiváis (1998), imagen para efectos ilustrativos.

La recreación de la realidad responde a la tradición y a la incorporación de esta en la Modernidad mexicana. Un ejemplo más lo es Jesús Fidencio Síntora Constantino, conocido como El niño Fidencio, un ícono de la religiosidad popular (ver Imagen 4). Este, debido a sus poderes, es un referente a través del cual, la experiencia particular, suma creencias y devociones propias de la tradición.

La visión fidencista, vívida en la primera mitad de siglo XX, pero vigente hasta nuestros días (Zavala, 1998), le permite al cronista extrapolar esta devoción popular que a 1984 (momento en que escribe Monsiváis), contrasta significativamente con el manejo que hacen las revistas y, en general, los medios de comunicación de prácticas propias de la religiosidad popular. 
Para el cronista:

Una nueva tradición del sincretismo combina el catolicismo como práctica de masas, la peregrinación como meta en sí misma (el viaje al santuario es la parte más recompensante), el curanderismo, el espiritualismo trinitario mariano y la personalidad carismática que, intente o no fundar religiones, se usa a sí misma como filtro de la experiencia religiosa (p. 107).

\section{Imagen 4. Jesús Fidencio Síntora y El niño Fidencio}
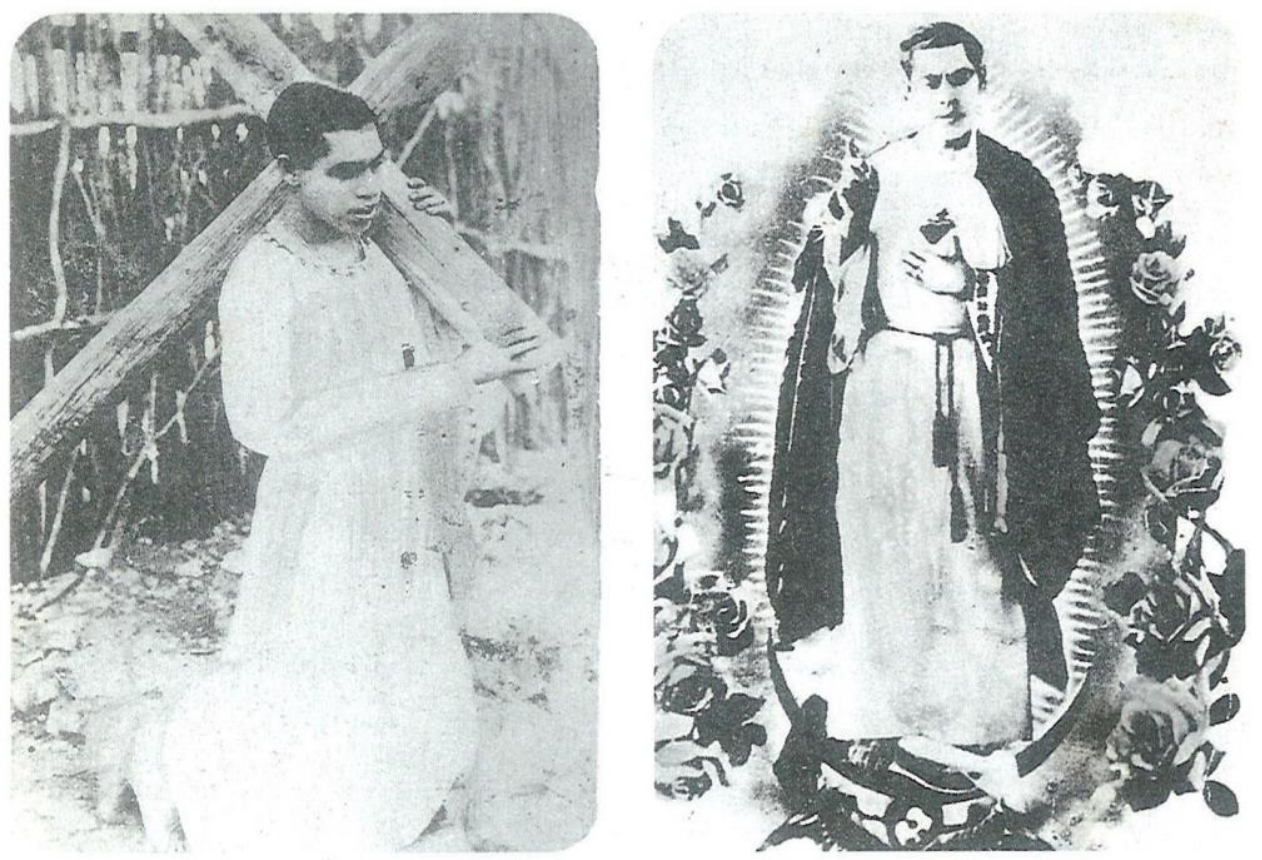

Jesús Fidencio Síntora Constantino, El niño Fidencio

Fuente: Los rituales del caos de Carlos Monsiváis (1998), imágenes para efectos ilustrativos.

Así, en las dos imágenes que se incluyen y se rescatan, se connotan por un lado la vida de sacrificio del Santo, y por otro, su entronización. El concepto monsivaisiano de la "mística de la marginalidad" describe esta como una práctica anclada en la relación con la visión católica, la fe y su vivencia cotidiana; la cual a su vez, se asocia a todos los aspectos de la vida catalogados de sagrados y que son parte de la cotidianidad moderna: popular y aristocrática.

Esas prácticas rituales de la cultura popular también se tienen con la lucha libre. Rodolfo Guzmán, El Santo (ver Imagen 5) recoge la elaboración de un mito urbano: “el 
Santo: [es] una fábula realista de nuestra cultura urbana; una vida profesional cuya primera razón de ser fue la carencia de rostro; una fama sin rasgos faciales a los cuales adherirse" (p. 133). La lucha libre es una actividad por medio de la cual las clases populares ven una promesa de ascenso y esta se nos recuerda en la imagen de El Santo, al ser llevado en hombros:

Hay luchadores de su calidad o tal vez mejores, pero El Santo es un rito de la pobreza, de los consuelos peleoneros dentro del Gran-Desconsuelo-que-es-laVida, la mezcla exacta de tragedia clásica, circo, deporte olímpico, comedia, teatro de variedad y catarsis laboral (p. 128).

\section{Imagen 5. Rodolfo Guzmán, El Santo}

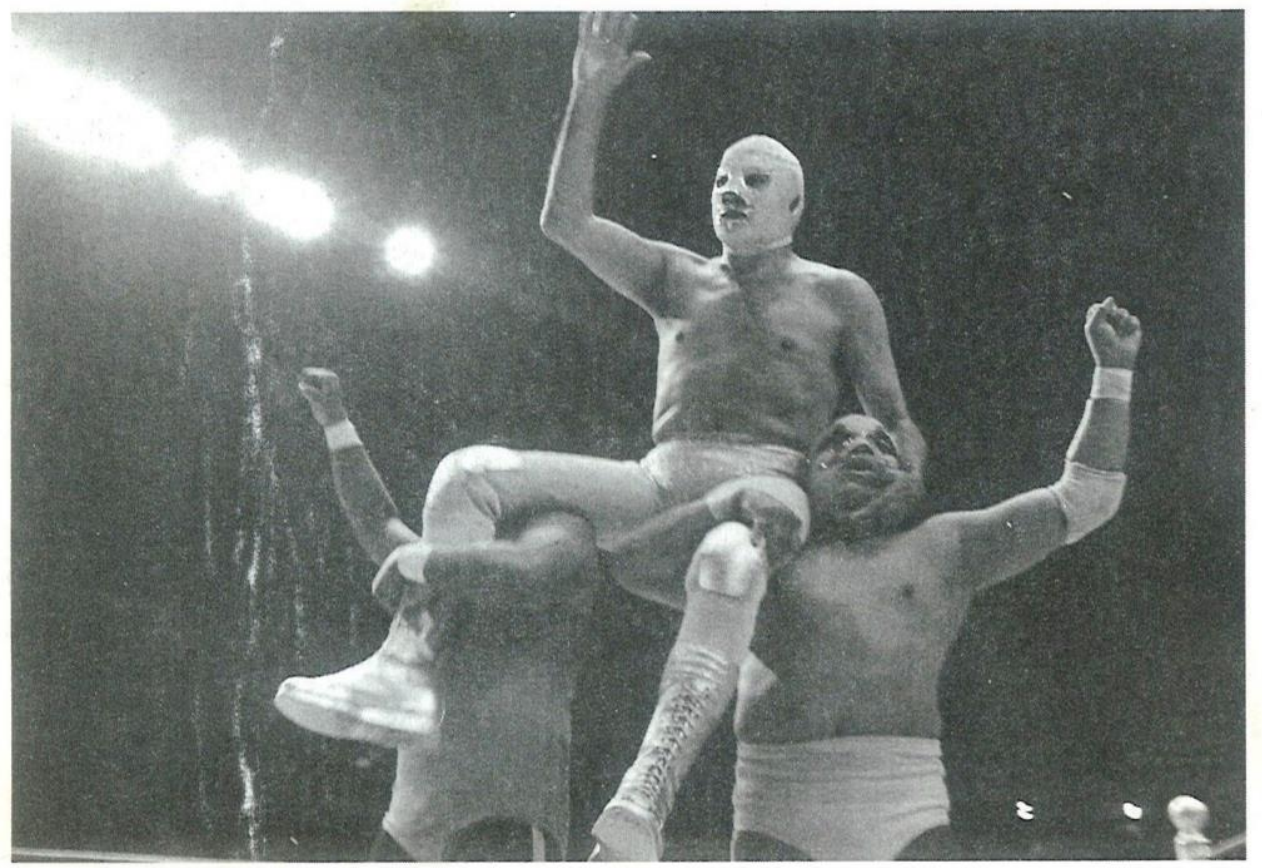

Rodolfo Guzmán, El Santo @ particular

Fuente: Los rituales del caos de Carlos Monsiváis (1998), imagen para efectos ilustrativos.

Gloria Trevi y los condones viene a fortalecer la caracterización de lo popular (ver Imagen 6). En la fotografía se expone el uso del cuerpo -sobre todo femenino-, que ha sido vetado de la esfera pública en una sociedad latinoamericana tradicionalmente católica. Trevi confronta y genera controversia. Ella cuenta una historia que es su propia historia y deconstruye un orden social hegemónico patriarcal asociado a la sexualidad y al ser mujer. 
Esta imagen tiene un punto de encuentro con el estilo que irrumpe la cantante como solista en 1989, pues según Monsiváis su actitud y forma de vestir "pertenecen a lo de hoy", además de que está marcada "con el signo del escándalo". Y es que en su popularidad "intervienen la audacia y la franqueza y el juego erótico y la apariencia frágil y cachonda y la energía y la voz gruesa” (p. 169), donde las letras desenfadadas le dan un símbolo de anticonformismo y rebeldía a la juventud, principalmente la femenina. Ese desenfado es patente en los condones que luce, muestra de un empoderamiento, y quienes se ven representadas en ella ven un "estilo contagioso, que le permite a las mujeres utilizar el mismo vocabulario que los hombres" (p. 170). Es ahí donde los géneros y sus roles sexuales se acortan, dándole un nuevo viraje en una descarga de energía y lujuria. De hecho, es esa imagen controversial la que acompañan sus conciertos, donde hostiga verbalmente a los hombres, los sube al escenario y los desviste. Trevi introduce una especie de voyeurismo que se convierte en el elemento disuasorio en relación con lo que puede hacer la mujer, proyectando a su vez un cambio.

\section{Imagen 6. Gloria Trevi y los condones, fotografía de Maritza López}

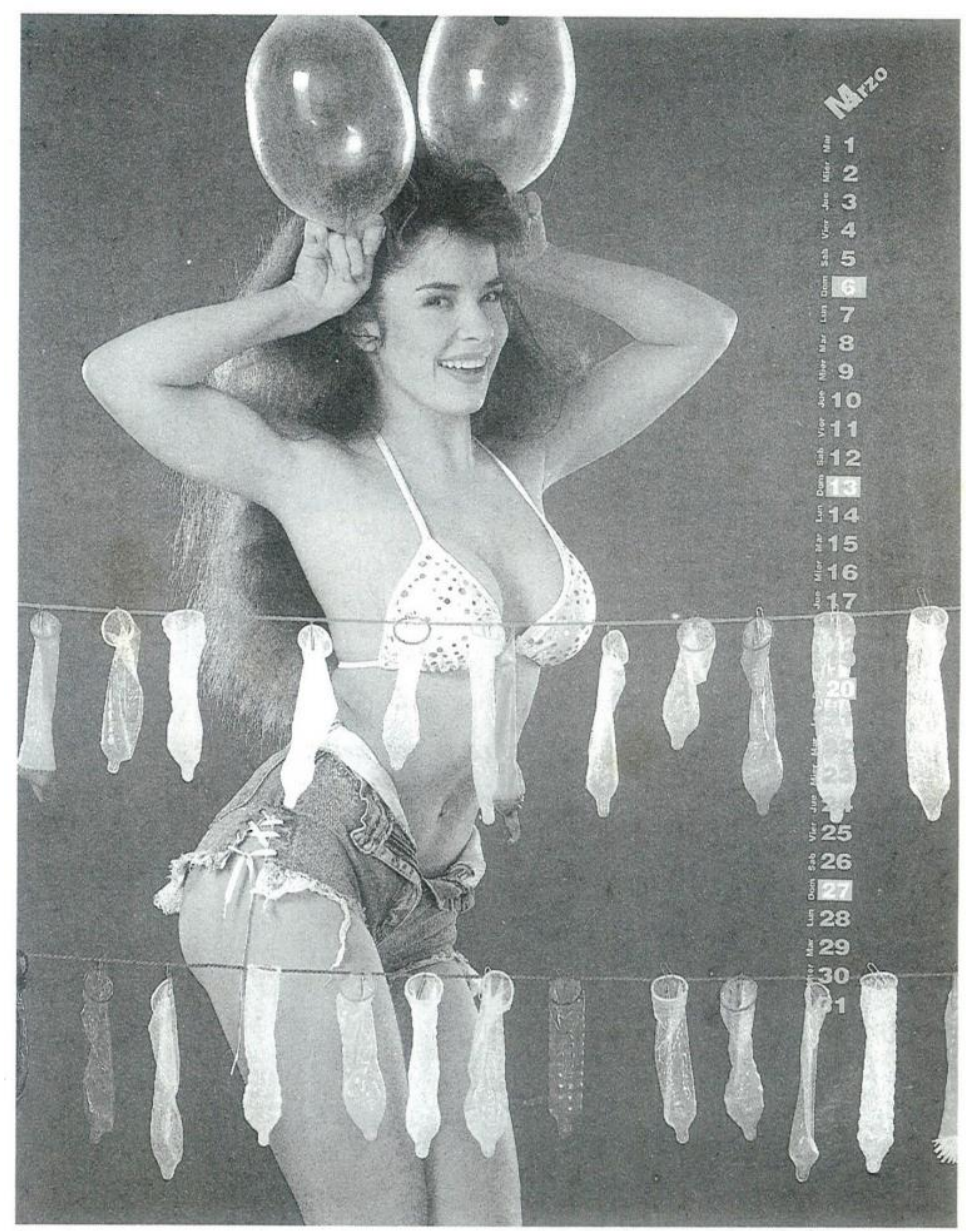

Gloria Trevi y los condones (c) Maritza López 
Fuente: Los rituales del caos de Carlos Monsiváis (1998), imagen para efectos ilustrativos.

En relación con la tónica de la transgresión, Vienes Santo en Iztapalapa nos recuerda la muerte de Jesús, pero también el ahorcamiento de Judas, visible en los pies de un hombre que ha sido colgado (ver Imagen 7). No debe obviarse la escenificación que anualmente se realiza en Iztapalapa de la pasión y la asistencia de multitudes, con lo que se expresa, nuevamente, la visión demográfica y el crecimiento de la ciudad, lo religioso y la traición; y, por qué no, lo diferente, lo Otro.

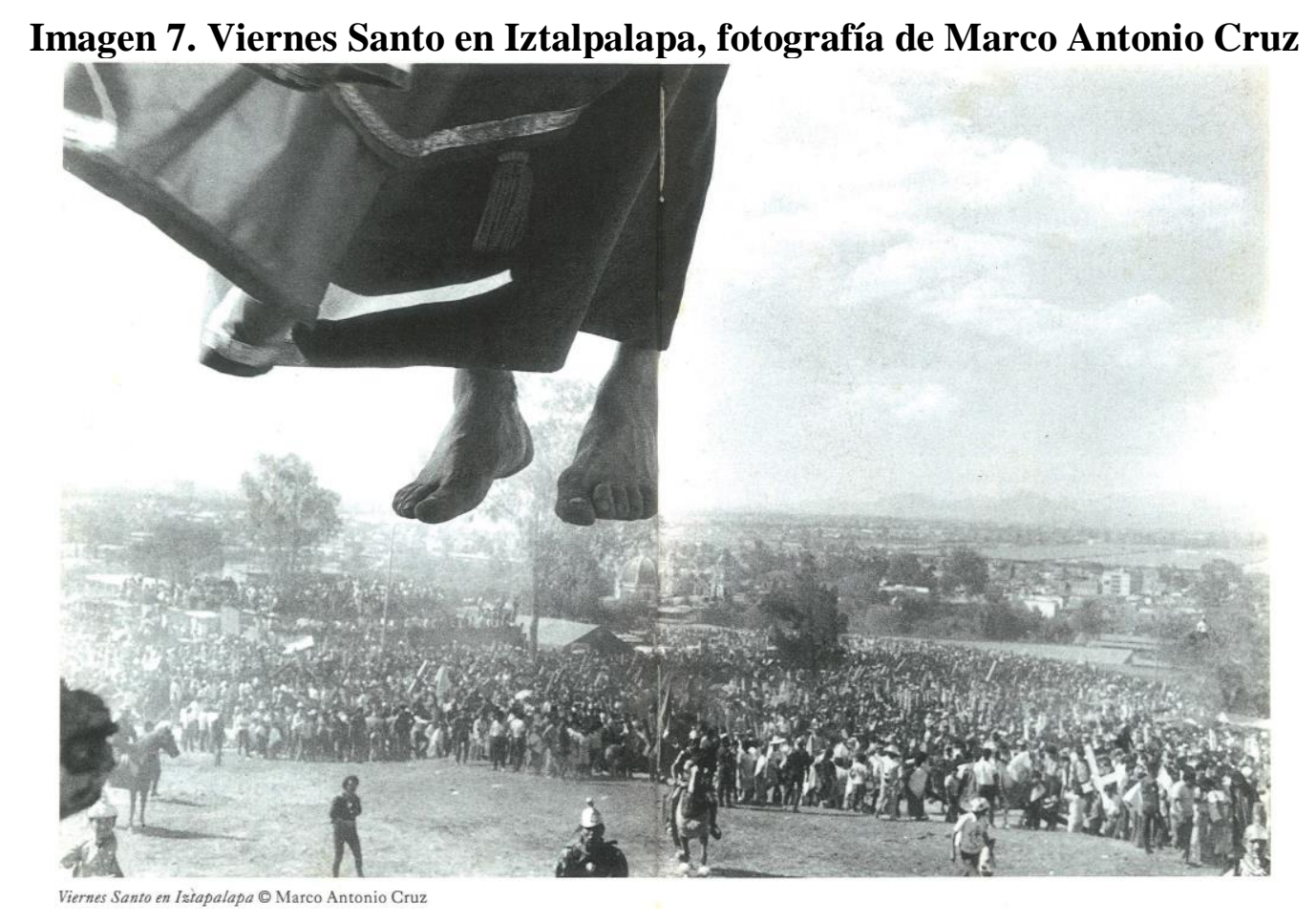

Fuente: Los rituales del caos de Carlos Monsiváis (1998), imagen para efectos ilustrativos.

Un significado patente en lo religioso y lo deportivo es el nacionalismo que se da a través de estas formas de evidenciar lo popular. Julio César Chávez se convierte, al igual que El Santo, en un ídolo popular, que encarna lo popular, y bajo el que se despliega el discurso de lo mexicano, no en vano lleva una bandera de México en la fotografía (ver Imagen 8).

Tanto en la imagen como en la crónica que remite al boxeador, se da cuenta de la pelea del 20 de febrero de 1993. Apunta Monsiváis: 
¿Quién sabe algo del retador, el norteamericano Greg Haugen? Es un accidente de la vida, porque Jei Ci debe pelear con alguien, y por eso a Haugen se le atribuyen declaraciones antimexicanas, para concederle perfil de infamia, pero las frases hirientes ya no provocan la ira, si eso piensa es cosa suya (p. 29).

Interesa la exaltación de lo mexicano y la mediatización del acontecimiento, evidencia del espectáculo como nuevo generador de la realidad social.

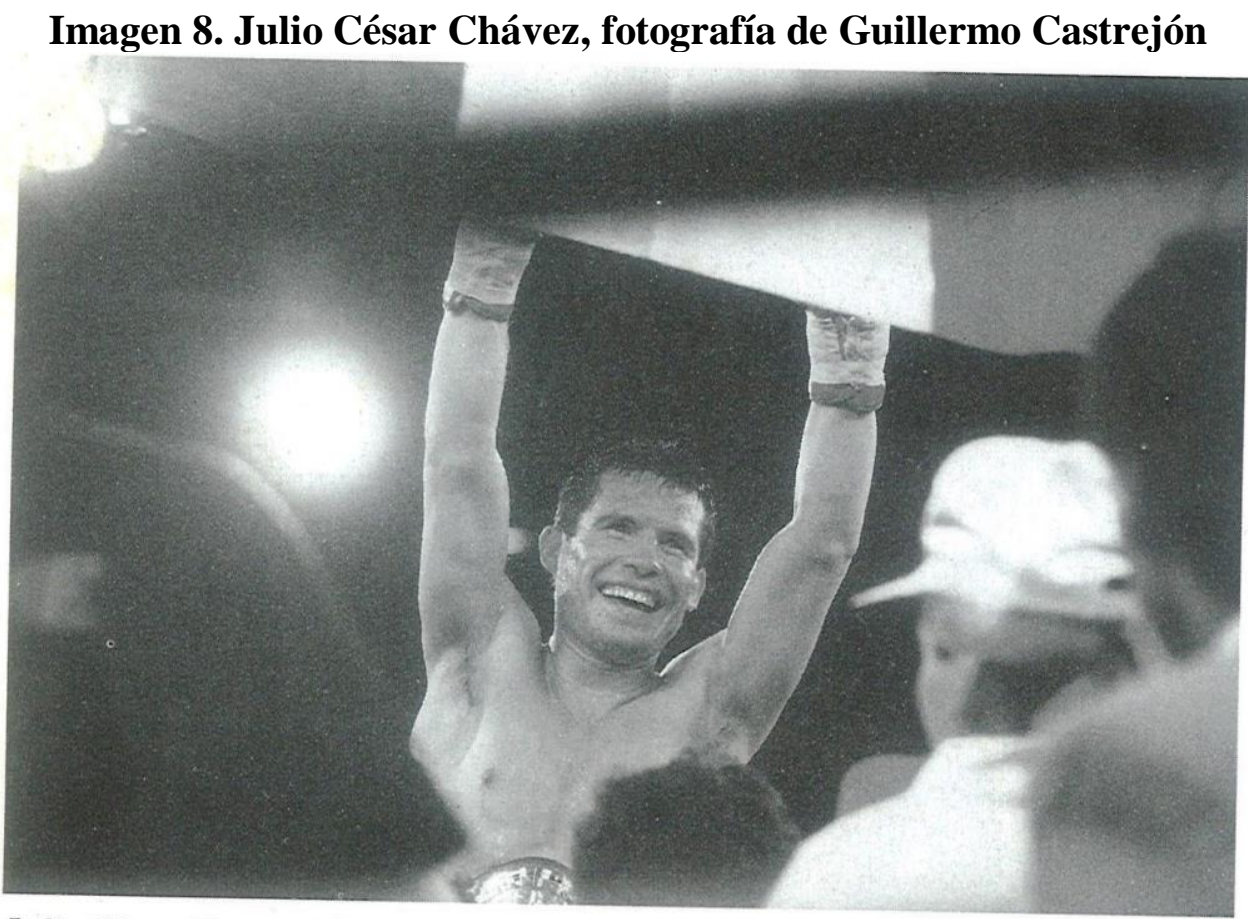

Julio César Chávez @ Guillermo Castreión

Fuente: Los rituales del caos de Carlos Monsiváis (1998), imagen para efectos ilustrativos.

Algo similar sucede con la celebración de la guadalupana y de los Peregrinos en la Basílica, indígenas que ritualizan sus tradiciones y bailan en honor a TonantzinGuadalupe (ver Imagen 9). 


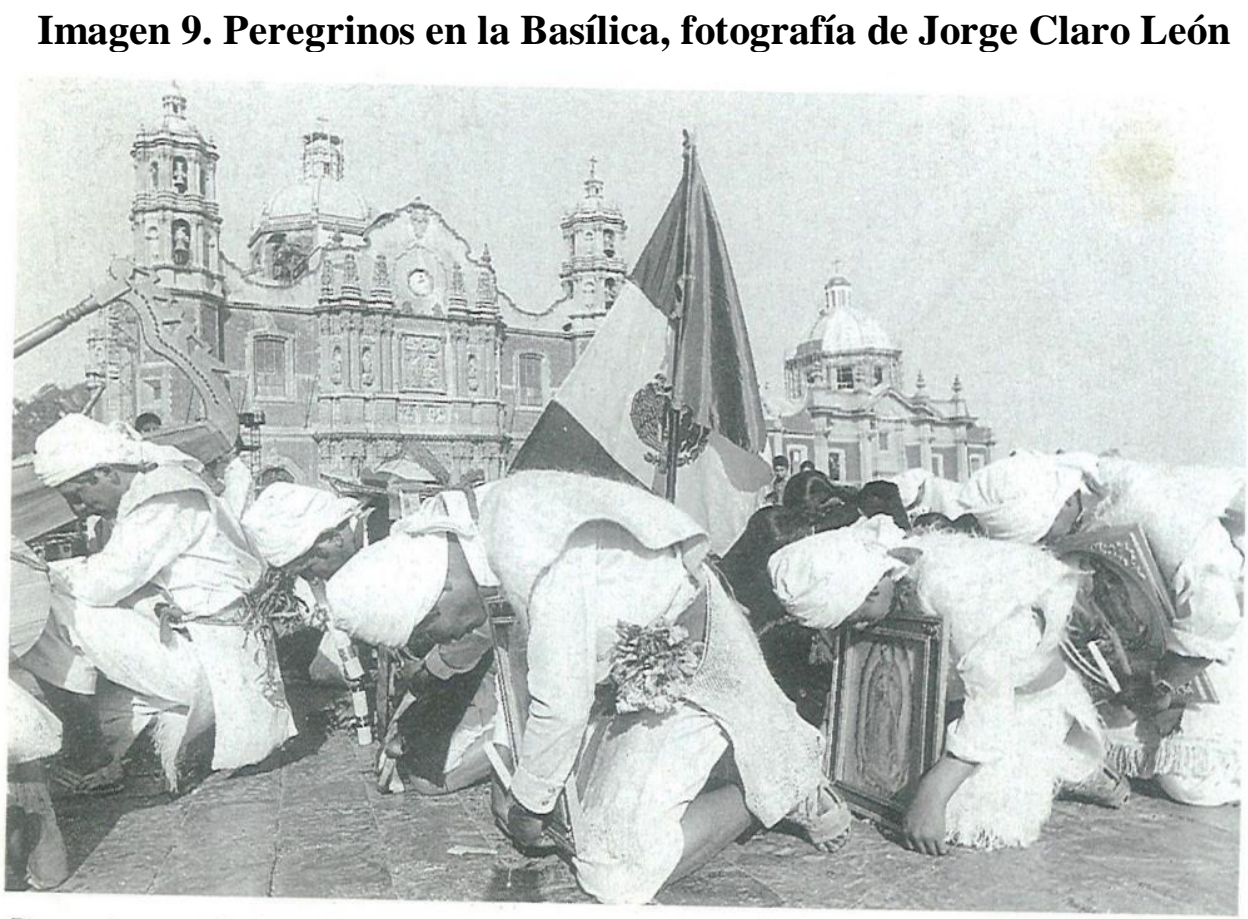

Peregrinos en la Basílica $@$ Jorge Claro León

Fuente: Los rituales del caos de Carlos Monsiváis (1998), imagen para efectos ilustrativos.

Se muestra el sincretismo religioso, la transculturalidad (Segre, 2007; Spitta 1995), el arraigo moderno sobre la tradición y formas postradicionales del nacionalismo:

Históricamente, el guadalupanismo, acervo de arraigo y continuidad, es la forma más encarnizada del nacionalismo, ¿pero qué sucede en un mundo postradicional? ¿Cuál es la relación entre nacionalismo y guadalupanismo? Según creo, más que de pasión belicosa, se puede hablar de lazos que igualan logros y limitaciones: la miseria, la comprensión del mundo a través de actos rituales, el desamparo, las costumbres, el amor estremecido por los símbolos, el sincretismo como vía de adaptación (primero a la Conquista, luego a la nación que surgía entre batallas, más tarde a la modernización), el fanatismo que es también un testimonio corporal del arraigo en primer aprendizaje (p. 40).

Aunado a ello, las celebraciones de los partidos de la Selección Mexicana de Fútbol en Estados Unidos 1994 reviven también la visión nacionalista y la mediatización de la vida a través del espectáculo. Al igual que con lo religioso, la Celebración futbolera en el Ángel expresa la necesidad del pueblo de liberarse de las 
represiones y de la vida que está demarcada por el malestar en la cultura (ver Imagen 10). En la foto, un grupo de jóvenes se muestran con insignias del Tri, bañados en lodo.

\section{Imagen 10. Celebración futbolera en el Ángel, fotografía de Jorge Claro León}

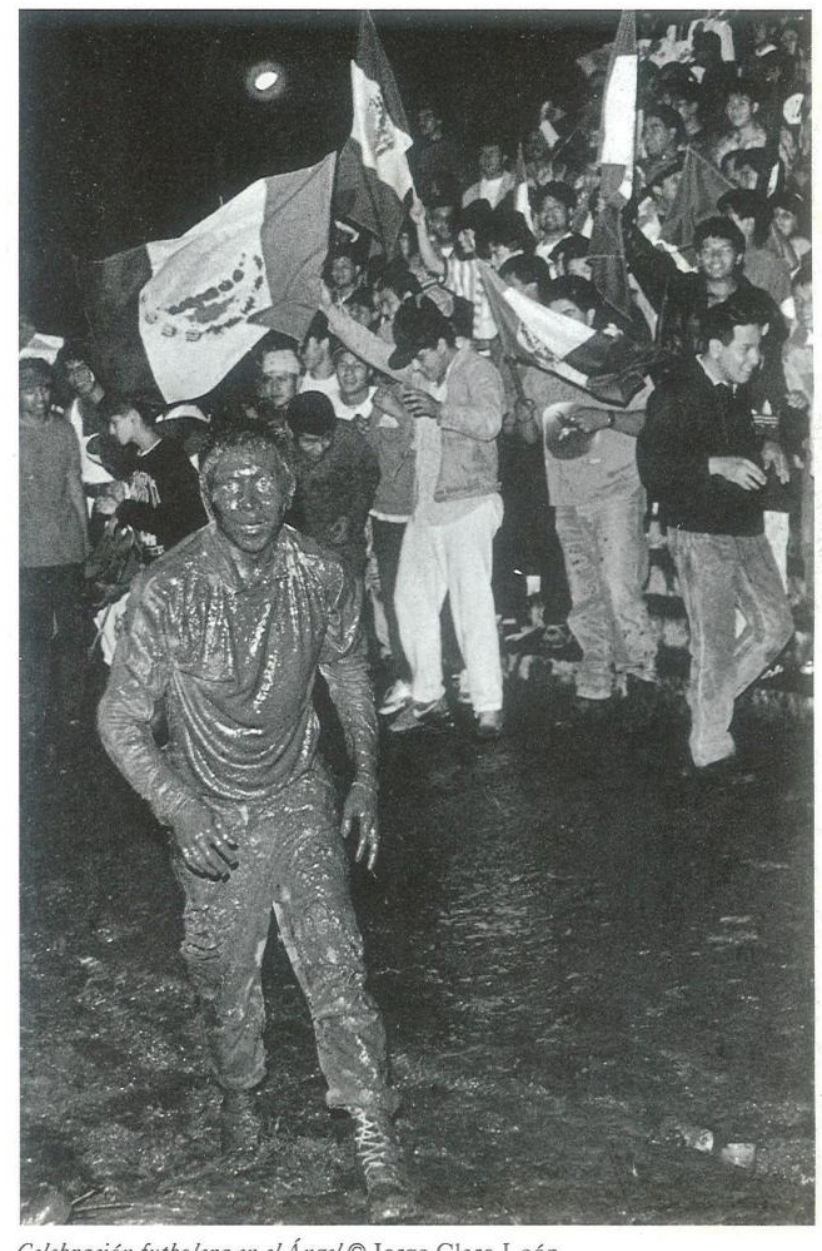

Celebración futbolera en el Ángel @ Jorge Claro León

Fuente: Los rituales del caos de Carlos Monsiváis (1998), imagen para efectos ilustrativos.

En la imagen se da cuenta de que:

El Ángel es un símbolo freudiano, el juego de futbol representa el ser nacional en abstracto, la reacciones ante el Tri son festejos postnacionalismo, la tele empequeñece la realidad para engrandecer nuestro ánimo, y él mismo, el sabio futbolero [que puede ser cualquiera de los presentes en la foto], es una falsa demostración de la ley de gravedad (pp. 36-37).

Así es como la ciudad, en tanto escenario, vive día a día los rituales que dan lugar a las costumbres y a las tradiciones, pero también la forma en la que esta toma vida propia, negando la lógica moderna del orden. Nos dice el cronista que: 
En el Distrito Federal la obsesión permanente (el tema insoslayable) es la multitud que rodea la multitud, la manera en que cada persona, así no lo sepa o no lo admita, se precave y atrinchera en el mínimo sitio que la ciudad le concede (p. 17).

Y eso es lo que se presentan en Balneario y El Metro, espacios de interacción social completamente saturados, en los cuales la vida cotidiana se desborda (ver Imagen 11 e Imagen 12).

\section{Imagen 11. Balneario, fotografía de Francisco Mata Rosas}

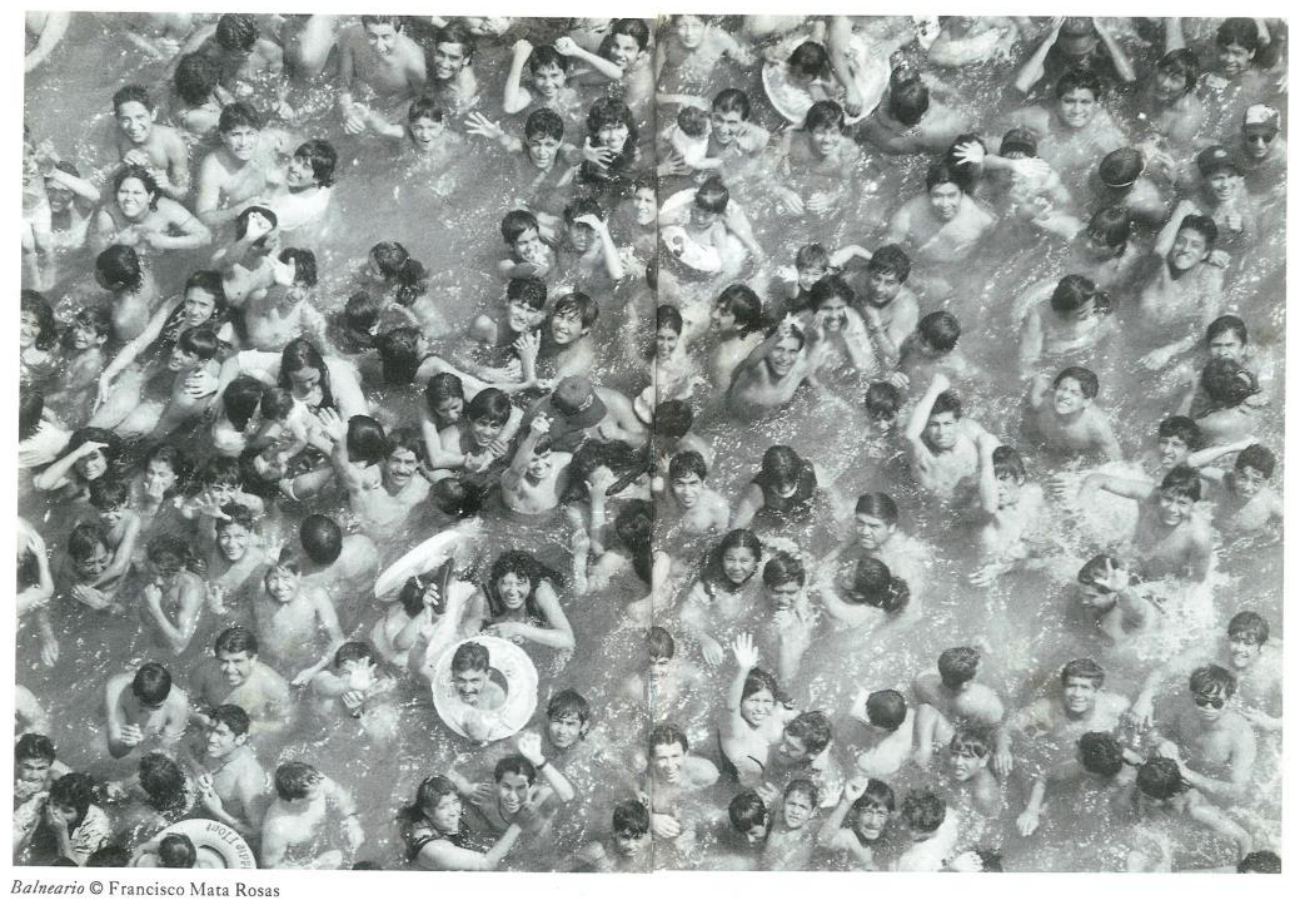

Fuente: Los rituales del caos de Carlos Monsiváis (1998), imagen para efectos ilustrativos. 


\section{Imagen 12. El Metro, fotografía de Guillermo Castrejón}

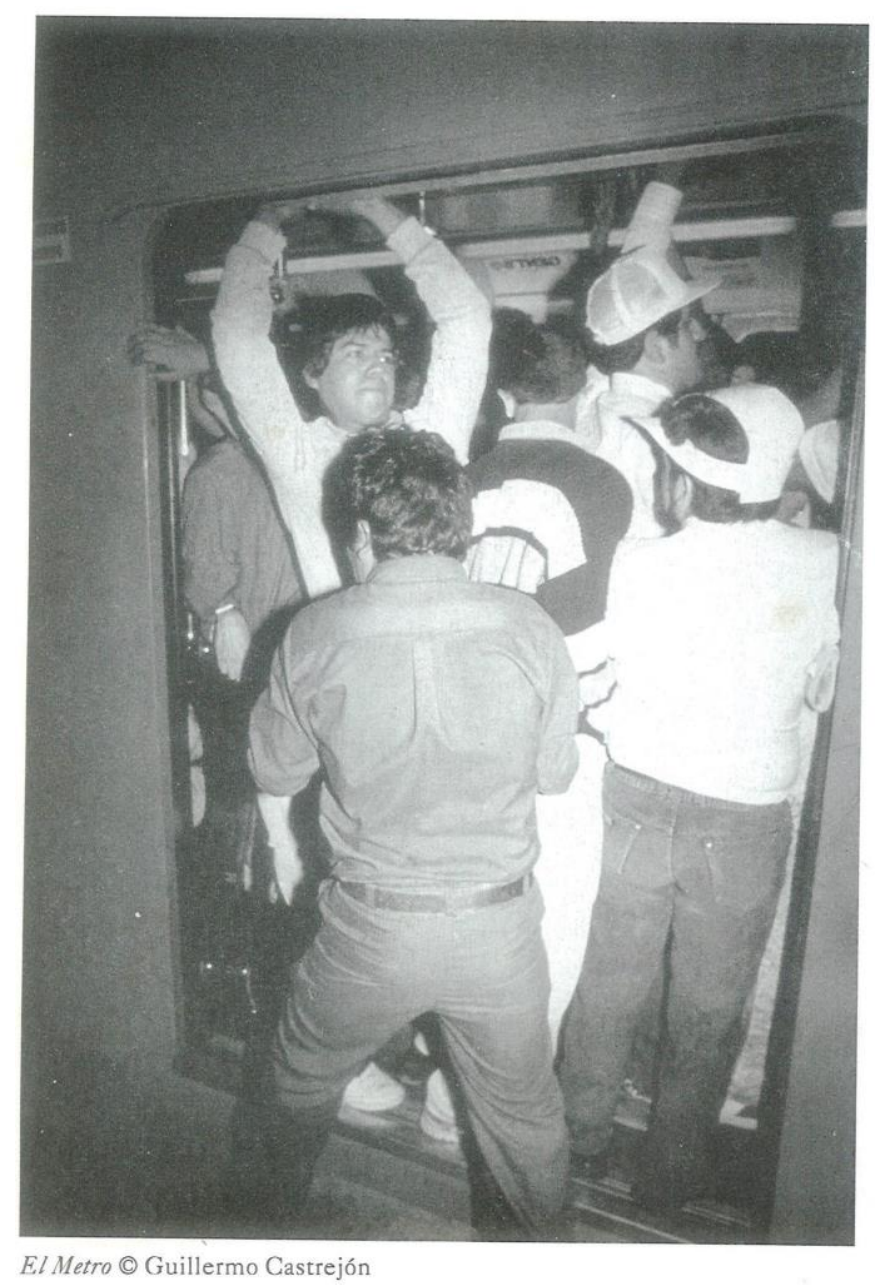

Fuente: Los rituales del caos de Carlos Monsiváis (1998), imagen para efectos ilustrativos.

El cuestionamiento en ambas imágenes es hacia la calidad de vida, la forma en la cual el espacio vital humano da lugar a lo que Monsiváis llama apretujamiento, "El Metro anula la singularidad, el anonimato, la castidad, la cachondería; todas ésas son reacciones personales en el horizonte donde los muchos son el único antecedente de los demasiados. Aquí entrar o salir da lo mismo" (p. 112).

Por último, resulta importante rescatar que, en la representación monsivaisiana, los medios de comunicación tienen un protagonismo claro. La cultura de masas y la multitud juegan con los conciertos, los artistas y la puesta en marcha de nuevas formas de movilización social. Así como Gloria Trevi, Luis Miguel se convierte en un ídolo de 
las nuevas generaciones en los años de la década de 1990 (ver Imagen 13), donde el espectáculo envuelve a las masas.

\section{Imagen 13. Luis Miguel, fotografía de Rogelio Cuéllar}

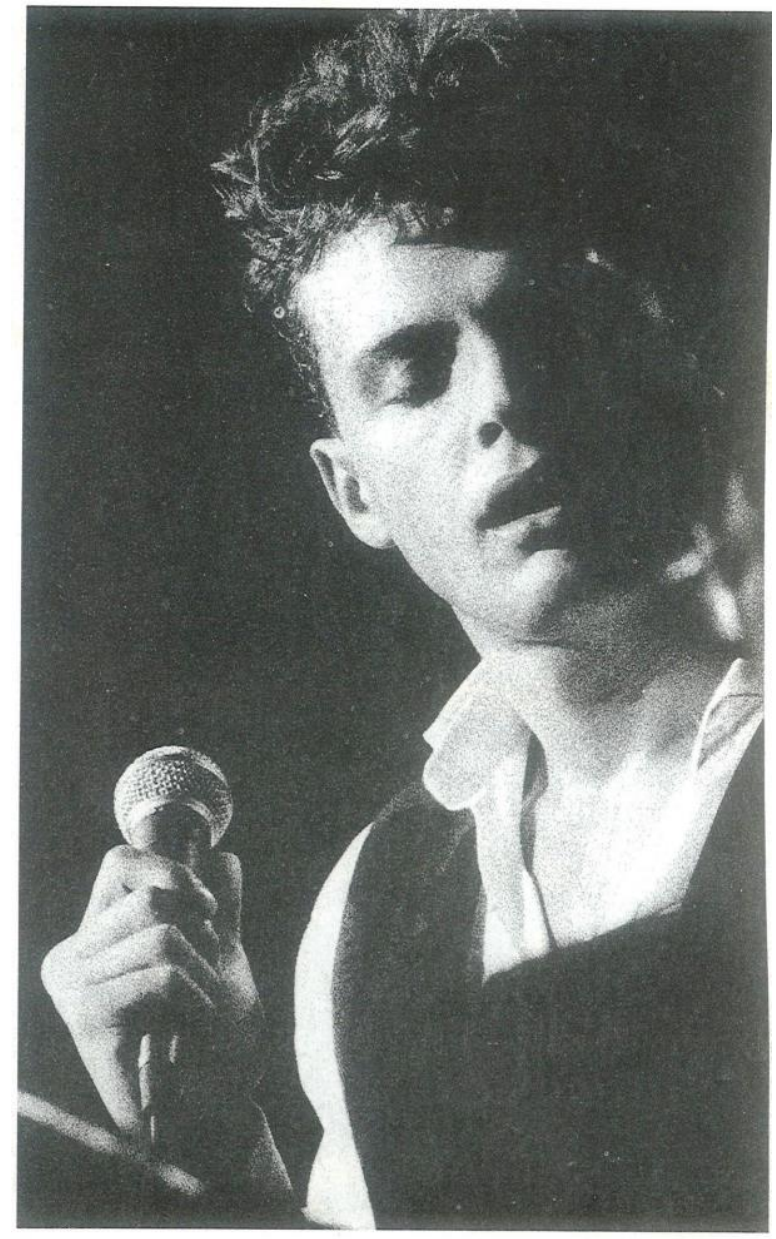

Luis Miguel @ Rogelio Cuéllar

Fuente: Los rituales del caos de Carlos Monsiváis (1998), imagen para efectos ilustrativos.

Ese cambio contrasta con el ascenso paulatino de estrellas, que hacia mediados de siglo era potenciado por el cine, como sucede con "La Doña", en la Época de Oro del Cine Mexicano (1940-1950). De ahí que María Félix en el Zócalo es justamente eso, el contraste de la transición a la Modernidad y la eclosión de la globalización (ver Imagen 14).

Redada nos remite al inicio de esta crónica de imágenes: los jóvenes. En Monsiváis, la reflexión de la juventud y del control que se da en la sociedad tiene su asidero en mayo de 1968. Esta fotografía nos recuerda que ante el desorden y las nuevas formas que encaran la cotidianidad finisecular de México, el poder siempre está 
presente como regulador de la sociedad, imponiéndose y sometiendo, al igual que lo hace el consumo con la población.

Nótese que la multitud, la identidad y el espectáculo son los elementos con que juegan estas representaciones visuales, planteándonos una reflexión crítica del contexto, del crecimiento de la ciudad, de la sobrevivencia de la tradición y la rearticulación de identidades en pluralidad; del papel que juegan los medios de comunicación como constructores de la vida contemporánea.

\section{Imagen 14. María Félix en el Zócalo, fotografía de Alejandro Britto}

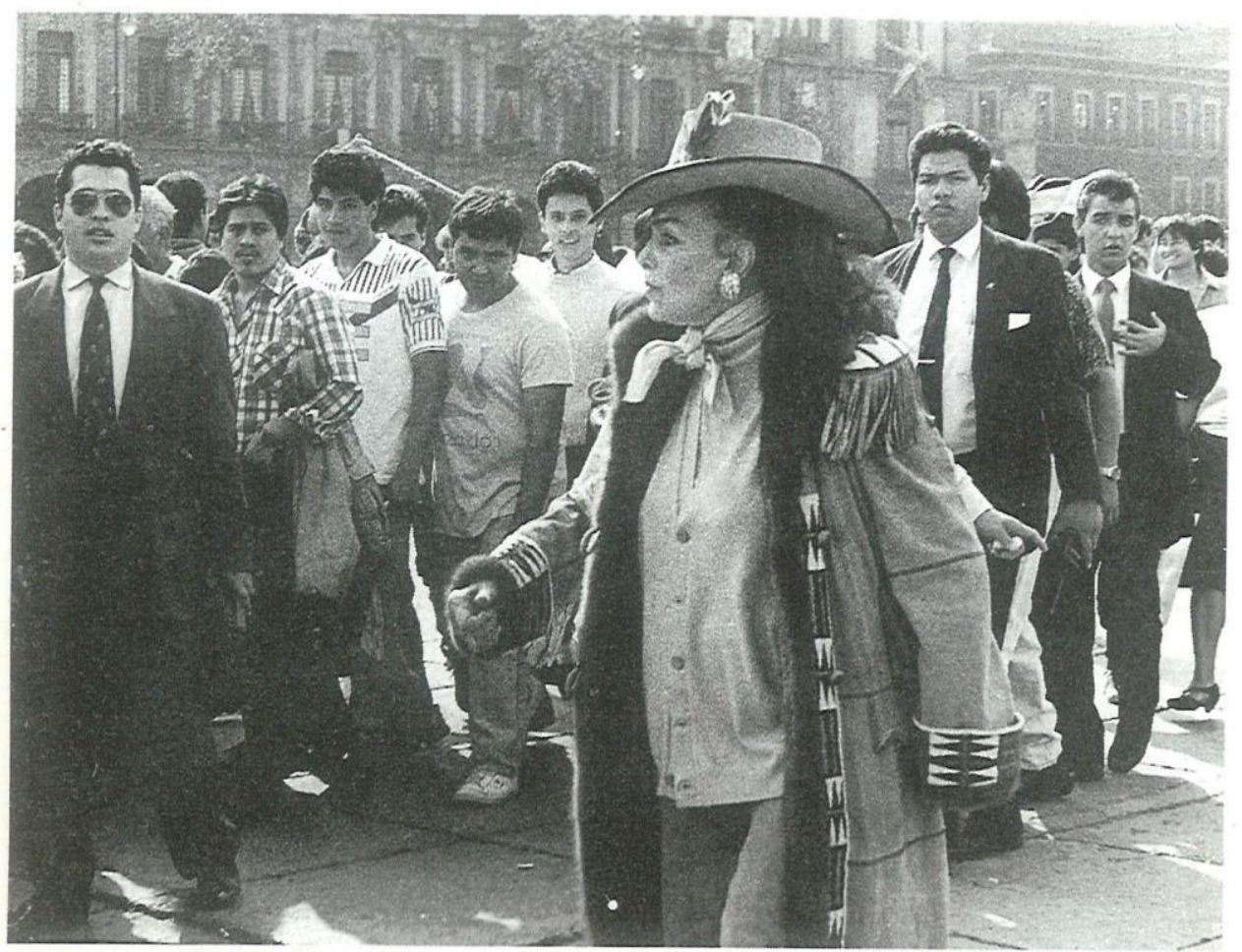

María Félix en el Zócalo @ Alejandro Brito

Fuente: Los rituales del caos de Carlos Monsiváis (1998), imagen para efectos ilustrativos. 


\section{Imagen 15. Redada, fotografía de Marco Antonio Cruz}

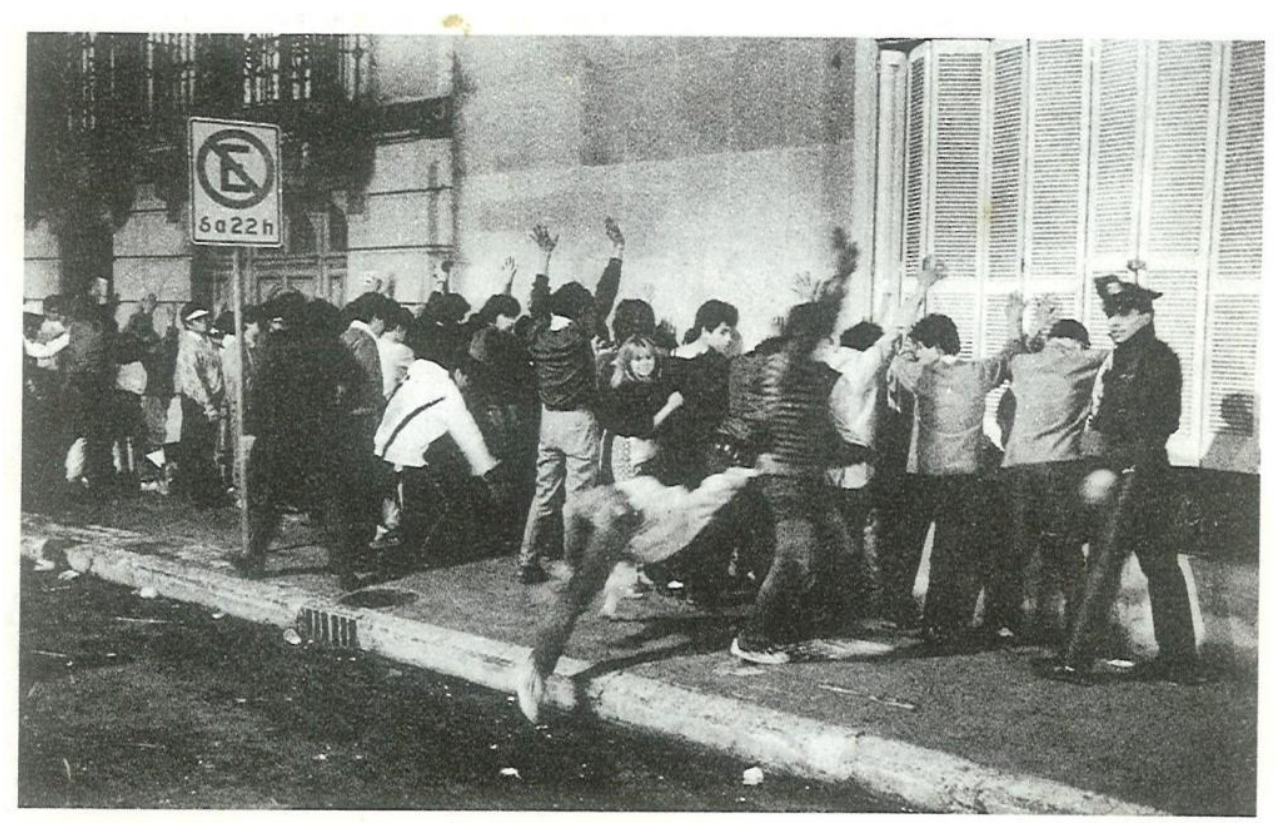

Redada $@$ Marco Antonio Cruz

Fuente: Los rituales del caos de Carlos Monsiváis (1998), imagen para efectos ilustrativos.

Al respecto Pérez, en ocasión del texto México en sus imágenes de John Mraz (2014) nos indica que la fotografía es una de las fuentes fundamentales para la historia de los siglos XIX y XX de México, haciendo las veces de testigos polivalentes "son ventanas al pasado y al presente, constituyen fuentes fundamentales del conocimiento de las sociedades y de las épocas que las producen" (2014, p. 12). Asimismo, indica que las representaciones visuales han contribuido a la construcción de la identidad mexicana, a lo que agregamos que hoy reconfiguran críticamente la historia de su Modernidad. Esto se evidencia en la confluencia de elementos disímiles que hayan justo en el desorden y el caos una posibilidad para su expresión conjunta. Aspecto que a todas luces Monsiváis ha tenido presente.

\section{Las contradicciones de la Modernidad mexicana}

Las imágenes incluidas en Los rituales del caos y la situación social descrita en las crónicas nos presentan una serie de aspectos que vistos con la óptica de la Modernidad, evidencian la manera en la cual ha operado en el entorno mexicano la lógica occidental. En ambas representaciones, en la crónica y en la imagen, se nos muestra la influencia del proyecto civilizatorio moderno que se ha configurado y ha 
permanecido desde la conquista hasta nuestros días, potenciando no solo una lógica propia, sino una transculturación entendida como una mixtificación donde ambas raíces culturales, indígena y occidental, se hayan presentes (Segre, 2007).

En ese sentido, la Modernidad de la cual hablamos es aquella que se nos ofrece como una promesa (Berman, 2010), y ha sido susceptible de crítica en la segunda mitad de siglo XX, poniendo de manifiesto, como apuntó Larraín (2000) para América Latina, que es un fenómeno complejo y multidimensional.

La Modernidad corresponde a una estructura institucional particular que se desarrolla en Europa Occidental y Estados Unidos, pero cuya aplicación en otros estratos como el latinoamericano supone una serie de principios y significados que no necesariamente suceden de la misma forma ni pueden operar contextualmente en la misma dirección, lo que da lugar a múltiples modernidades (Larraín, 2005).

En el espacio latinoamericano se atestigua, además, la existencia de una categoría que complejiza la puesta en marcha del proyecto moderno: la tradición. Categoría que pone entre dicho los principios de autonomía y control que se arguyen para la Modernidad (Larraín, 2005). El proyecto emancipador, expansivo, renovador y democratizador moderno (García, 1990) no se ve obstaculizado directamente por la tradición, como vemos con lo postradicional de Monsiváis. Pero, al no considerar la diversidad cultural, el mismo proyecto excluyó a la mayoría de la población junto con sus prácticas y creencias, las cuales, a todas luces, buscan sobrevivir.

Resulta importante para la comprensión de esta configuración de la Modernidad, la diferenciación que Bonfil (2012) realizó para la sociedad mexicana: un México imaginado que no necesariamente coincide con la realidad y un México profundo que resulta ser inaccesible en muchos casos, ya que "la cultura moderna se realizó negando las tradiciones y los territorios" (García, 1990, p. 48), aún con la permanencia de la tradición.

En la práctica, la presencia de la tradición no permite cumplir las operaciones de la modernidad europea y "nuestra modernidad" va a tener "un eco diferido y deficiente de los países centrales" (García, 1990, p. 69).

Monsiváis, consciente de la configuración de una Modernidad mexicana, apunta la subsistencia de prácticas tradicionales, lo cual se hace patente en los rituales de los indígenas el 11 de diciembre frente a la Basílica de Guadalupe, donde sostiene que: "aquí se exhibe lo ocultado el resto del año: el país sin acceso a la modernización por 
contagio" (p. 39). Y que también podemos aprehender a través del niño Fidencio y la lucha libre, entre otros.

El cronista pone de manifiesto esa diferenciación histórica que implica en el entorno latinoamericano el acceso a una visión externa que se propone como el camino a seguir. Esto se debe a la sedimentación, yuxtaposición y entrecruzamiento de las tradiciones de los indígenas con el hispanismo colonial católico y la visión moderna concentrada en acciones políticas propias del nacionalismo (García, 1990). Aquí, la secularización moderna no tiene efecto, ni en los sectores populares ni en ciertas élites que van a preservar un arraigo a las tradiciones para justificar la diferenciación social como vemos en la imagen de Helguera.

Es esa prevalencia de la tradición, la del México profundo (Bonfil, 2012), la cual despliega una perspectiva moderna heterogénea y multitemporal, que atestigua la particularidad de la historia de la modernización latinoamericana, la cual sigue desplegándose en el México de fin de siglo. Incluso adopta nuevas formas: "tradición es también disponibilidad de elementos, y desde hace tiempo las tribus de danzantes se visten como pueden" (p. 49), es decir, se moldea de acuerdo a las posibilidades que el contexto brinda, incorporando el uso de lo moderno como parte del ritual tradicional, tal cual sucede con la celebración indígena frente a la Basílica de Guadalupe.

Existen tres características fundamentales de la Modernidad que podemos rescatar de las representaciones visuales que Monsiváis incluye en el libro, las cuales coinciden con los planteamientos modernos de ciencia, razón y progreso (Larraín, 2000): el ritual como mitificación del orden moderno, la racionalidad como resistencia ante la tradición y el progreso como proyecto de desarrollo.

La Modernidad supone un orden social que busca el equilibrio, ya no el fijado por Dios, sino por la "naturaleza", controlado por la participación del ser humano a través de la ciencia y la razón (Larraín, 2000). Ese orden es el que subyace en el ritual, pues a modo de semejanza de la naturaleza se propicia en su ejecución, el orden social (Balandier, 1990) y el dominio (Brünner, 1998).

Si bien el ritual "trabaja para el orden" como señala Balandier (1990), también se ocupa del desorden, y en tanto ambas son categorías inseparables del rito, le permiten a este imponer un orden global que resulta contradictorio e incierto. Esto coincide con lo que nos presenta Monsiváis, donde el “desorden” premoderno ${ }^{\dagger \dagger}$ está incorporado en

\footnotetext{
†† No en el sentido que lo utiliza Brünner (1998) quien los asemeja a un pre-capitalismo, sino más bien en las formas culturales no occidentales cuya herencia se plasma en la tradición.
} 
la Modernidad a través de la tradición. Hablamos aquí de lo religioso, de lo indígena, de la aglomeración en el metro, en los conciertos y, en general, de la vida en la ciudad.

De hecho, los rituales que se suscitan en el caos organizan, bajo el principio de orden de la Modernidad, la presentación de diferentes situaciones, así podemos hablar de rituales premodernos (los religiosos y mágico-religiosos), pero también modernos (los que evocan al nacionalismo) y posmodernos (los que se fundamentan en el consumo y los medios de comunicación). Todos hacen patente la lógica moderna como principio articulador de la realidad, es decir, hay un caos, pero este lo que hace es articular el orden de la vida mexicana. Así lo propone el cronista: “y en el caos inicia el perfeccionamiento del orden" (p. 15).

Ese orden está imbuido de otra característica clave de la Modernidad, la razón. La racionalidad moderna se entiende a partir del desarrollo de la ciencia y la “apropiación reflexiva del conocimiento" (Larraín, 2000, p. 26), la cual viene a colocarse en la base del sistema. El cronista reconoce la racionalidad que se demanda en la dinámica social, a pesar de las creencias populares. Es decir, la racionalidad sigue siendo el motivo que guía la explicación del mundo, y él deja ver que las formas racionales de conocimiento aún consideran como distorsionado y supersticioso las maneras en que los grupos, por lo general no educados en la lógica de Occidente, hacen sus explicaciones de acuerdo con la tradición (como la religiosidad popular). Su incorporación dentro del orden de la tradición y su naturalización en el espacio social, ponen en contradicción esta perspectiva racional, al punto que esa misma lógica tiende a aplicarse dentro de la cultura de masas con motivo de la tónica new age y los ideales de éxito y superación demandados.

Otro aspecto que podemos abstraer en el espacio social descrito y que tiene relación con otra característica visible en las imágenes es la del progreso. El planteamiento moderno conlleva la propuesta del crecimiento de la producción de bienes materiales, de ahí que "la modernización requiere la supremacía de la razón instrumental que maximiza el control y la productividad" (Larraín, 2000, p. 42).

El capitalismo se fija dentro de esta perspectiva como un Norte y adquiere una dimensión moderna, pero hay que recordar que en la Modernidad "el capitalismo es una forma histórica de expresión de la expansión del dominio racional, pero no la única" (Larraín, 2005, p. 19). Aun así, el progreso suscita una idea de mejoramiento, de esa 
promesa rearticulada en la visión de desarrollo y, hacia fines de siglo, se convierte en parte inherente a la lógica económica dominante.

En Monsiváis, la promesa moderna no es la misma para Norman Rockwell que Jesús Helguera (ambos ilustradores). El éxito económico tampoco, mientras el primero retrataba el "paisaje idílico de la Norteamérica de las clases medias, con sus porches de la felicidad conyugal, sus cenas de thanksgiving bendecidas por la paz del Señor" (p. 67), el sueño del tradicionalismo kitsch del segundo afirma una diferencia. Algo que también está en la producción en masa de artículos mexicanos que se venden en EE. UU.

Esa diferencia marcada entre el desarrollo estadounidense y el mexicano también sucede a lo interno de México entre quienes han asumido el proyecto moderno y quienes no. Ello se hace patente en las crónicas con descripción de quienes asisten a conciertos como el de Sinatra. Las nuevas generaciones de la élite se asumen garantes de la realización de esa promesa como en el caso de los artistas Luis Miguel y María Félix.

No obstante, "la gran oferta del Progreso resultó el ingreso a esa minoría afortunada, no más del tres por ciento a lo mejor, pero - de acuerdo al diseño utópicouna minoría jamás inalcanzable” (p. 219). Por ello es que el ideal de progreso a través del éxito persiste "me gustaría ser uno de los meros, tener ese automóvil tan sexy que vuelve inútiles a palabras seductoras y mujeres seducibles" (p. 213), siendo un sueño inalcanzable y contradictorio.

Así, la Modernidad de Los rituales del caos viene a hacer eco de una serie de contradicciones sistemáticas que se dieron en el entorno latinoamericano (García, 1990), y que en México adquieren gran relevancia, sobre todo si consideramos la gran cantidad de población y su atrincheramiento en un espacio urbano central. En la modernización propuesta por el proyecto moderno, se ciñe la hegemonía de las clases dominantes (Bonfil, 2012). A pesar de la expansión restringida del mercado, la tradición sostiene su primacía gracias a la falsa democratización para las minorías, y la consecuente poca eficacia de los procesos sociales (principalmente de la educación como medio de movilidad social).

Coincidimos con Larraín al plantear que:

América Latina sufre desde su independencia una ruptura cultural: su verdadera identidad cultural no es reconocida por sus propias elites, y el modelo racional 
ilustrado adoptado por ellas no sólo es por entero diferente, sino que totalmente opuesto a su verdadera identidad (2000, p. 179).

En Monsiváis, esta identidad "verdadera” no es más que la forma en la cual el pueblo llano concibe en su cotidianidad las transformaciones sociales de las cuales ha sido objeto (una mirada de los otros). Por ello, lanza la crítica al sistema, partiendo de la representación de lo popular y mostrando su integración a una sociedad de masas que viene a seguir perpetuando la exclusión, el caos.

Sin duda, esto es producto de la irrupción de la Modernidad y su mezcla con modalidades de organización de la cultura que la lógica de Occidente no contempló: “es en esos escenarios donde estallan más ostensiblemente casi todas las categorías y las parejas de oposición convencionales (subalterno/hegemónico, tradicional/moderno) empleadas para hablar de lo popular" (García, 1990, p. 263).

De ahí que sea en la cultura popular donde se concibe la síntesis de la identidad, evidenciada a partir de la exclusión y la marginalidad de la cual los sujetos han sido objeto, y que tiende a reproducirse con mayor ahínco a final de siglo, a través de las demandas de consumo. Eso sucede con la religiosidad popular, con la lucha libre y el boxeo, con los conciertos y en la ciudad.

La Modernidad, en su variante latinoamericana, viene, por tanto, a sostener principios básicos que se adecuan a las características contextuales, las cuales son visibles en Los rituales del caos. Por ello, la permanencia de la tradición y los cambios que se generan en relación con la puesta en marcha del proyecto moderno, aunado al auge de la globalización, nos llevan a hablar de cambios culturales y de contradicciones (Díaz, 1999; Giddens, 1994, 1997; Lyotard, 1986, 1989; Vattimo, 1997).

\section{Conclusiones}

En el caso de Los rituales del caos, las crónicas y las imágenes que lo constituyen, posibilitan la caracterización de la situación social del México de fin de siglo. Se hace eco de una nueva articulación cultural que se afianzan en los cambios de las últimas cuatro décadas (García, 2011).

La referencia e inferencia del desarrollo industrial, el consumo y los medios de información son parte de una impronta económica que rearticula el proyecto moderno. En su representación se da una crítica a esta lógica económica que coincide con el interés del género literario. Al respecto, nos dice Montes que "la política de la crónica 
contemporánea comienza allí donde se plantea la ruptura de la distribución de los lugares fijos, de los saberes y de los no saberes, de las competencias y las incompetencias" (2014, p. 20, cursiva en el original).

Esa ruptura posibilita además, ir más allá del contexto que se critica y de la traducción de la cultura popular en la nueva sociedad de masas. También hay en la demanda de ese contexto un acceso a recursos propios del entorno que transforman el género literario.

Con ello, queremos decir que el texto no escapa al principio moderno de la escritura, pero la realidad representada al mismo tiempo se vuelve inabarcable. Esto genera una insuficiencia entre lo que el discurso escrito busca representar y lo que evoca, por lo que el cronista recurre a más pruebas de lo que sucede (las imágenes), con el fin de caracterizar el entorno.

Así, la vida retratada por el cronista y sugerida por las imágenes, es la expresión de un espíritu de época marcado por la irrupción de la globalización, que tiene injerencia tanto a nivel individual como colectivo; por un lado inquiere a quien escribe para demandar la toma de una posición crítica, y por otro se vale de lo que sucede para evidenciar lo que interesa cuestionar; "es la manifestación en la cultura de la civilización material emergente" (Brünner, 1998, p. 30).

Recordemos "la globalización de la cultura es la manifestación de las contradicciones, tensiones, desajustes y cambios a que dan lugar las interrelaciones $e$ interacciones entre los cuatro macro-fenómenos indicados [capitalismo, democracia, medios de comunicación y posmodernidad]" (Brünner, 1998, p. 30, cursiva añadida). Por lo tanto, la cotidianidad representada es una puerta a la reflexión y al conocimiento del México finisecular.

Para Monsiváis la contradicción que se genera entre ritual y caos es muestra de la discontinuidad entre lo moderno y de la diseminación de sentido. Hay un clima que se prefigura a partir de las características descritas, el cual es visible en las oposiciones típicas (tradicional/moderno, cultura de élite/sociedad de masas, campo/ciudad), ya sea porque los significados se traslapan o se adquieren otros.

Podemos afirmar a partir de lo que nos muestra el texto en estudio y lo representado en las imágenes, que la contradicción es clara en el espacio mexicano por la sobrevivencia de tradición, la cual responde a la manera en que la visión moderna externa se trató de implantar. La idea moderna se fija como proyecto pero en la práctica no se concreta debido a que no se podía omitir la visión de múltiples pueblos originarios 
que desde mucho antes tenían su vida y su cosmovisión definidas. La rearticulación de las creencias en lo religioso da muestra de ello, el intento por rescatar lo indígena e introducirlo en otros discursos también. Se contrasta que, mientras el modelo cultural racionalista ilustrado propicia la alienación de la población y se desprecian las masas "atrasadas", las tradiciones subsisten en medio de los fallidos intentos modernizadores (Larraín, 2000).

Esa síntesis cultural se afirma en la visión del pastiche, del bricolaje, del sincretismo, y es propia de la transculturación, la cual se traduce a fin de siglo XX en lo representado. De ahí que, tanto en la crónica como en la imagen, se da un juego de significación que evidencia la presencia de un discurso de poder que se perpetúa y de una tensión que se muestra en la expresión de la diversidad.

\section{Referencias bibliográficas}

Augé, Marc. (2000). Los no lugares: espacios del anonimato. Barcelona: Editorial Gedisa.

Balandier, George. (1990). El Desorden. La teoría del caos y las ciencias sociales. Elogio de la fecundidad en movimiento. Barcelona: Editorial Gedisa.

Barthes, Roland. (1986). Lo obvio y lo obtuso. Barcelona: Editorial Paidós.

Barthes, Roland. (2002). Mitologías. México D. F.: Siglo XXI Editores.

Barthes, Roland. (2005). La cámara lúcida. Barcelona: Editorial Paidós.

Baudrillard, Jean. (1974). La sociedad del consumo. Sus mitos, sus estructuras. Barcelona: Plaza y Janes S. A., Editores.

Beriain, Josexto. (1996). Las consecuencias perversas de la modernidad. Modernidad, contingencia y riesgo. Barcelona: Arthropos.

Berman, Marshall. (2010). Todo lo sólido de desvanece en el aire: la experiencia de la modernidad. Estado de México: Siglo XXI Editores S. A. de C. V.

Bhabha, Homi. (2002). El lugar de la cultura. Buenos Aires: Editorial Manantial.

Bonfil, Guillermo. (2012). México Profundo. México D. F.: Random House Mondadori, S. A. de C. V.

Britto, Luis. (1994). El imperio contracultural: del rock a la postmodernidad. Caracas: Editorial Nueva Sociedad.

Brünner, José Joaquín. (1998). Globalización cultural y posmodernidad. Santiago de Chile: Fondo de Cultura Económica. 
Burke, Peter. (2005). Visto y no visto. El uso de la imagen como documento histórico. Barcelona: Editorial Crítica.

Carrión, Jorge. (2012). Mejor que ficción. Crónicas ejemplares. Barcelona: Editorial Anagrama.

Castells, Manuel. (1972). La cuestión urbana. Madrid: Siglo XXI.

Chillón, Albert. (1999). Literatura y periodismo. Una tradición de relaciones promiscuas. Barcelona: Servei de Publicacions. Aldea Global.

Crary, Jonathan. (2008). Las técnicas del observador. Visión y modernidad en el siglo XIX. Murcia: CENDEAL.

Darrigrandi, Claudia. (2013). Crónica latinoamericana: algunos apuntes sobre su estudio. Cuadernos de literatura, XVII(34), 122-143.

Díaz, Luis Felipe. (1999). Semiótica, psicoanálisis y posmodernidad. San Juan: Editorial Plaza Mayor.

Egan, Linda. (2004). Carlos Monsiváis: cultura y crónica en el México contemporáneo. México, D. F.: Fondo de Cultura Económica.

Flórez, Rubén Darío. (2010). "Carlos Monsiváis, el descifrador de los discursos populares. Entre la imagen y el enunciado". Forma y Función, 23(1), s. p. Recuperado de http://www.revistas.unal.edu.co/index.php/formayfuncion/article/viewFile/18171/ 19082

García, George. (2011). La posmodernidad y sus modernidades: una introducción. 19 Serie Cuadernos de Historia de la Cultura. Escuela de Estudios Generales. San José: Editorial Universidad de Costa Rica.

García, Néstor. (1990). Cultura híbridas. Estrategias para entrar y salir de la modernidad. México, D. F.: Editorial Grijalbo S. A. de C. V.

Giddens, Anthony. (1994). Consecuencias de la modernidad. Madrid: Alianza Editorial. Habermas, Jürgen. (1989). Modernidad: un proyecto incompleto. Casullo, N. (comp.), El debate modernidad posmodernidad. Buenos Aires: Punto Sur.

Harvey, David. (1990). The Condition of Posmodernity. An Enquiry into the Origins of Cultural Change. Cambridge: M.A. Blackwell.

Hedbidge, Dick. (2004). Subcultura. El significado del estilo. Barcelona: Editorial Paidós.

Jameson, Frederic. (2001). Teoría de la Postmodernidad. Madrid: Editorial Trotta, S. A. 
Jaramillo, Darío. (2012). Antología de crónica latinoamericana actual. Madrid: Alfaguara.

Larraín, Jorge. (2000). Modernidad, razón e identidad en América Latina. Santiago: Editorial Andrés Bello.

Larraín, Jorge. (2005). ¿América Latina moderna? Globalización e identidad. Santiago: LOM Ediciones.

Lyotard, Jean François. (1986). La posmodernidad (explicada a los niños). Barcelona: Gedisa.

Lyotard, Jean François. (1989). La condición posmoderna. Madrid: Cátedra.

Mailer, Norman. (2005). América. Barcelona: Anagrama.

Manzor, Lillian. (1996). Borges/Escher, Sarduy/CoBrA: un encuentro posmoderno. Madrid: Editorial Pliegos.

Mendoza, Edgar. (2005). Lo urbano y la ciudad: la importancia de su construcción teórica. Guatemala: Universidad de San Carlos.

Monsiváis, Carlos. (1998). Los rituales del caos. México, D. F.: Ediciones ERA, S. A. de C. V.

Montes, Alicia. (2014). Políticas y estéticas de representación de la experiencia urbana en la crónica contemporánea. Buenos Aires: Corregidor.

Moscovici, Serge. (1984). El fenómeno de las representaciones sociales. Cambridge: University Press.

Mraz, John. (2014). México en sus imágenes. México D. F.: Artes de México y del Mundo S. A. CONACULTA.

Panofsky, Erwin. (1983). El significado de las artes visuales. Madrid: Alianza.

Pintos, Juan Luis. (1995). Los imaginarios sociales: la nueva construcción de la realidad social. Madrid: Editorial Sal Terrae.

Rotker, Susana. (2005). La invención de la crónica. Buenos Aires: Fondo de Cultura Económica.

Sarlo, Beatriz. (2003). Una modernidad periférica: Buenos Aires 1920 y 1930. Buenos Aires: Ediciones Nueva Visión.

Segre, Erica. (2007). Intersected identities. Strategies of visualization in nineteenth and twentieth-century Mexican culture. New York y Oxford: Berghahm Books.

Shohat, Ella y Stam, Robert. (2002). Multiculturalismo, cine y medios de comunicación. Barcelona: Editorial Paidós. 
Spitta, Silvia. (1995). Between two waters. Narratives of Transculturation in Latin America. Houston: Rice University Press.

Taylor, Charles. (2005). Imaginarios sociales modernos. Barcelona: Paidós.

Urrutia, Víctor. (1999). Para comprender ¿Qué es la ciudad? Teorías sociales. Navarra: Editorial Verbo Divino.

Vattimo, Gianni. (1998). La sociedad transparente. Barcelona: Ediciones Paidós Ibérica, S. A.

Williams, Raymond. (1997). La política de Modernismo: contra los nuevos enfoques conformistas. Buenos Aires: Manantial.

Zavaleta, Antonio. (1998). "El Niño Fidencio and the Fidencistas". En: Zellner, William y Marc Petrowsky. Sects, Cults, and Spiritual Communities: a sociological analysis. Westport, CT: Praeger Publishers.

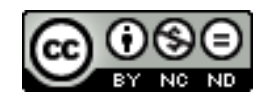

Esta obra está bajo una licencia de Creative Commons Reconocimiento-NoComercial-

SinObraDerivada 4.0 Internacional 